\title{
Protocolo, historia y desarrollo de las Iglesias Protestantes.
}

\section{Protocol, history and development of the Protestant Churches.}

\author{
Enrique Somavilla ${ }^{1}$ \\ CTSA, UPSA \\ enrisom@gmail.com
}

Recepción: 12/04/18 Revisión: 02/06/18 Aceptación: 17/06/18 Publicación: 30/06/18

\begin{abstract}
Resumen
El anglicanismo, cuyo origen se remonta a la Iglesia de Inglaterra, con Enrique VIII, constituye hoy una comunión de Iglesias de tipo episcopal que se mantienen unidas a la sede de Canterbury. La Iglesias Luteranas, provienen de la reforma del siglo XVI emprendida por Martín Lutero. Su lucha fue por la reforma de la Iglesia de Cristo. La Iglesias reformadas o presbiterianas son aquellas comunidades herederas del reformador Juan Calvino. Todas provienen del mismo tronco, pero su dispersión ha sido muy determinante. Es decisivo tener en cuenta cómo el conjunto de estas Iglesias, tratan de mantener ciertos vínculos con la Iglesia católica. Su liturgia ha ido perdiendo riqueza y fuerza ante la masiva depuración hecha por las distintas Iglesias y Comunidades eclesiales. Aún con todo poseen un protocolo y un ceremonial muy interesante, después de su separación de Roma, en el año 1520, fecha histórica de la cristiandad occidental.
\end{abstract}

Palabras claves: Anglicanismo, protestantismo, reforma, protocolo, precedencia, tratamiento.

\section{Abstract}

The Anglicanism, which origin goes back to the Church in England by the times of Henry VIII, constitutes a community of Episcopal churches in unity with Canterbury seat. The Luteran Churches come from the Reform in the XVI century with Martin Luther's leading. Martin's goal was to reform Christ's Church. The Presbyterians and the Reformed Churches are the heiress communities of John Calvin's Reform. All of them have the same origin, however their dispersion has been very important to determinate their outcomes. It is very important to take into account the way these groups of Churches tried to keep some kind of links with the Catholic Church. Their liturgy has lost richness and strength progressively due to the

\footnotetext{
${ }^{1}$ Director del Centro Teológico San Agustín de el Escorial.
} 
depuration made by the different churches and ecclesial communities. And yet, they have a very interesting protocol and ceremonial after their break-up with Rome in 1520, a historical date on the western Christianity.

Keywords: Anglicanism, Protestantism, Reform, protocol, precedence, treatment..

\section{Sumario}

1. Protocolo y ceremonial de la Iglesia anglicana o Comunión anglicana

2. Historia de la Iglesia Española Reformada Episcopal

3. Protocolo y ceremonial de las Iglesias Reformadas

4. Iglesia Evangélica española

5. Diferencias entre la Iglesia católica y las Iglesias de la Reforma en Teología

6. ¿Cuáles son las diferencias básicas entre las Iglesias de la Reforma y la Iglesia católica romana, respecto a la disciplina litúrgica?

7. Las Iglesias surgidas de la Reforma Protestante

8. Los servicios religiosos

9. Indumentaria litúrgica

10. Precedencias y tratamientos

11. Conclusión

12. Bibliografía

13. Webgrafía

\section{PROTOCOLO Y CEREMONIAL DE LA IGLESIA ANGLICANA O COMUNIÓN ANGLICANA}

La Iglesia de Inglaterra o Comunión anglicana se mantuvo cerca de las posturas de la Iglesia católica hasta perder el tema de la sucesión apostólica, zanjada durante el pontificado de León XIII ${ }^{2}$. Respecto a su liturgia se puede decir que "las reglas generales relativas a los colores litúrgicos no se definieron formalmente en el protocolo de la Iglesia de Inglaterra o Church of England, antes del siglo XVI con la rectificación de los misales durante el pontificado de Pío $V$, e incluso en tal secuencia se permitieron ciertas licencias. En la Inglaterra previa a la Reforma, el verde y el amarillo se consideraron intercambiables y así, cualquiera de ellos se podía usar con independencia de los siguientes tiempos: los domingos después de la Epifanía, los domingos después de la Santísima Trinidad y los días ordinarios de la semana. Las variaciones regionales persistieron; además, las Iglesias concretas podían recurrir a sus mejores vestiduras, sin tener en cuenta el color para la celebración de las principales festividades. Las Iglesias reformadas ignoraron, como norma general, el color litúrgico. La costumbre inglesa, como siempre, varió y no fue hasta mediados del siglo XIX y como resultado del Movimiento de Oxford y de la Sociedad Eclesiológica de Cambridge,

\footnotetext{
${ }^{2}$ Tras una reunión de la Congregación del Santo Oficio, el 16 de julio de 1896, se votó unánimemente en contra de la validez de dichas ordenaciones. El papa León XIII publicó la Bula Apostolicae curae, de 13 septiembre 1896.
} 
cuando la atención renovada hacia las ceremonias implicó la restauración de la secuencia de los colores litúrgicos, tanto en los vestidos como en los ornamentos (ropajes y adornos).

Los presbíteros evangélicos se resistieron a este movimiento tachándolo como Papismo, y los sacerdotes de la Alta Iglesia lo consideraron como una vuelta a las prácticas de la antigua Iglesia inglesa anterior a la Reforma. Como era de esperar, el mercantilismo victoriano vio la institución de los colores habituales y apropiados como una oportunidad industrial y comercial. Al final, todos salvo la mayoría de las parroquias pertenecientes a la Baja Iglesia, lucieron algún toque de color de temporada"”3.

En cuanto al gobierno de la Iglesia anglicana, la cabeza espiritual de la Iglesia de Inglaterra es el arzobispo de Canterbury, que es además obispo Primado de toda Inglaterra y Metropolitano de la Provincia de Canterbury. Tiene tratamiento de Reverendísimo. La reina tiene el título constitucional de Gobernador Supremo de la Iglesia de Inglaterra. Los colores litúrgicos son similares a la Iglesia católica con ligeras variaciones ${ }^{4}$.La autoridad suprema, desde 1919, la ejerce el Sínodo General, o Church Assembly ${ }^{5}$, compuesto por obispos y representantes del clero y laicos, elegidos al efecto, y sus resoluciones, llamados cánones, las tienen que aprobar el Parlamento británico, sin enmendarlas, y recibir el consentimiento de la reina para ser consideradas parte de la legislación inglesa ${ }^{6}$. La reina inaugura el Sínodo tras las elecciones que son cada cinco años ${ }^{7}$. Para todos los efectos la Iglesia Anglicana ${ }^{8}$, respecto a la liturgia, los tres, arzobispo, obispo y deán, vestirán normalmente de blanco y dorado. Alba blanca sobre la sotana y capa. No utilizarán casulla, como ocurre en la Iglesia católica, normalmente ${ }^{9}$. El arzobispo de Canterbury llevará la Cruz de Canterbury, el báculo de oro y amatistas, en forma de cruz, regalo de la reina Victoria, y que se parece al que han utilizado tanto el papa Benedicto XVI como Francisco. Sólo él llevará báculo, como máximo responsable de la Iglesia. Tanto el obispo de Londres, como el arzobispo, llevarán la mitra en la cabeza ${ }^{10}$. El anglicanismo cuenta con una liturgia algo más compleja, resultado del hecho de querer diferenciarse de la Iglesia católica, en el que al principio se adhirió y siguió en toda su estructura y organización. Su culto se fundamenta especialmente en "El Libro de Oración común". Los anglicanos siguen el Libro de Oración común $^{11}$, sin demasiados cambios desde el siglo $X V I^{12}$. Hubo una serie de sucesivas

\footnotetext{
${ }^{3}$ Cf. http://www.victorianweb.org/espanol/religionConsultado el 17-03-2015.

${ }^{4}$ Cf. W. H. St. J. Hope - E. G. C. F. ATCHLEY, "English Liturgical Colours", 1918, en P. F. BradshaW, The New SCM Dictionary of Liturgy and Worship, London 2005, pp. 120-122; P. DEARMER, The Ornaments of the Ministers, London 1908 y 1920; J. W. LEGG, Notes on the History of Liturgical Colours, London 1882.

${ }^{5}$ Cf. M. DeVIE, The Church of England, London 2008, pp. 28-58.

${ }^{6} \mathrm{Cf}$. https://protocoloalavista.wordpress.com/tag/iglesia-anglicana/ Consultado el 17-03-2015.

${ }^{7}$ Cf. M. DEVIE, The Church of England, London 2008, pp. 59-67.

${ }^{8}$ Cf. http://www.churchofengland.org/about-us/history.aspx Consultado el 17-03-2015.

${ }^{9} \mathrm{Cf}$. CHURCH HOUSE, Common Worship:Services and Prayers for the Church of England.Ordination Services, London 2007, pp.167-169.

${ }^{10}$ Cf. http://auladeprotocolo.blogspot.com.es/Consultado el 17-03-2015.

${ }^{11}$ Cf. Liturgia Anglicana o Libro de Oración común y Administración de los Sacramentos, y otros ritos y ceremonias de la Iglesia, según el uso de la Iglesia de Inglaterra, Londres 1923. Se trata de una colección de liturgias y oraciones que son producto del movimiento de reformación o renovación, que ocurrió en la Iglesia
} 
adaptaciones llevadas a cabo en el tiempo. La Iglesia anglicana se interesó en la liturgia ${ }^{13} y$, en particular, en la práctica de la Comunión ${ }^{14}$. Poco a poco, la indumentaria para el ceremonial se alteró con la adopción de los trajes tradicionales romanos de la Edad Media, como eran las estolas, casullas, capas pluviales ${ }^{15}$.El misal inglés es de $1912^{16}$, era una fusión del rito eucarístico del año 1662, el Libro de Oración Común y las oraciones en latín del Misal Romano, incluyendo las rúbricas que indiquen los actos más importantes. Enrique VIII es excomulgado por el papa Clemente VII en 1533. El cisma se produce entre 1533-1547. Desde 1547 hasta 1550 los tres primeros años de su sucesor Eduardo $\mathrm{VI}$, todas las órdenes se confirieron según el Ritual romano y con la debida intención, ya que aún se conservaba fielmente la doctrina de la Iglesia católica; por tanto, todas aquellas ordenaciones fueron consideradas como válidas.

Por el contrario, en el año 1550 entró en vigor el Book of Common Prayer (Libro de oración pública) de Eduardo VI. En éste, el Ritual romano era sustituido por el Ordinal Eduardino, que tanto en la ordenación de los sacerdotes como en la consagración de los obispos omitía la especificación de la potestad conferida. Se cometía por lo tanto un error sustancial de forma. Por lo que hace a la intención, en el Prayer Book del 1550, no solamente se negaba el sacramento del Orden, sino que en la celebración de la Cena con la que había sido sustituida la Misa, se eliminaba toda idea de sacrificio y de consagración y conversión del pan y del vino en el cuerpo y sangre de Jesucristo. Faltaba por lo tanto la intención necesaria en cuantos se acomodasen a la mentalidad del Prayer Book.

Conforme al ordinal eduardino y consiguientemente con los dos defectos sustanciales indicados fueron conferidas en la Iglesia Anglicana todas las órdenes tanto sacerdotales como episcopales hasta el año 1662. En esta fecha los dirigentes de la Iglesia Anglicana, conscientes de la indeterminación de la fórmula de consagración, trataron de corregirla, añadiendo la expresión del oficio respectivo de sacerdote o de obispo. Pero esta corrección, dado que confiriese a la fórmula la significación conveniente, vino demasiado tarde cuando,

cristiana en Europa en el siglo XVI, este movimiento se llama la Reforma Protestante. La Iglesia Anglicana Ortodoxa se mantiene firme al Libro de Oración Común, en sus ediciones clásicas de Londres 1662 y 1928. Consideramos la versión 1662 como la estándar de nuestra diócesis. Cualquiera pregunta sobre nuestra liturgia se resolverá por referencia a la versión de 1662.

12 Cf. S. NeILl,El Anglicanismo, Barcelona 1966; R. BARÓN, “La vida litúrgica de los anglicanos”, en Diálogo Ecuménico 15 (1969) 315-322; J. NEWMAN, Vía media de la Iglesia anglicana. Conferencias sobre la función profética de la Iglesia anglicana considerada en relación con el sistema romano y con el protestantismo popular, Salamanca 1994; K. BARTH, La oración según los catecismos de la Reforma,Salamanca 1980; S. NEILL, "Necesidad del episcopado: preguntas y respuestas anglicanas", en Concilium 80 (1972) 525-536.

${ }^{13}$ Cf. CHURCH House, Visual Liturgy Live, London 2006, pp. 52-66.

${ }^{14}$ Cf. CHURCH HOUSE, Common Worship:Services and Prayers for the Church of England. Festivals, London 2008,pp, 207-265.

${ }^{15} \mathrm{Cf}$. CHURCH House, Common Worship:Services and Prayers for the Church of England. Ordination Services London 2007, pp.164-165.

${ }^{16}$ Cf. ChURCH House, Common Worship: Services and Prayers for the Church of England. Pastoral services, London 2015, pp. 9-12. 
transcurrido un siglo largo en el uso de la fórmula inválida, se había ya extinguido ciertamente la jerarquía y con ella la potestad de ordenar.

Acerca del tema de las ordenaciones anglicanas, el papa León XIIII, procedió con la máxima prudencia que requería el asunto. Comenzó por designar una comisión de eclesiásticos eruditos pertenecientes a varias naciones para que estudiasen a fondo la cuestión. La comisión, realizado el encargo, presentó el fruto de sus investigaciones a la Sagrada Congregación del Santo Oficio ${ }^{17}$.

Más tarde, después de examinados diligentemente todos los documentos y razones en pro y en contra, el Sumo Pontífice manifestó el resultado mediante la Bula Apostolicae curae $^{18}$, de 18 de septiembre de 1896, declarando inválidas las ordenaciones anglicanas, en virtud del doble defecto sustancial antes señalado: el defecto de la fórmula y el defecto de intención. Para conferir un sacramento es necesario tener la intención de hacer lo que hace y realiza la Iglesia. Si un rito ha sido cambiado esencialmente o prácticamente no se le puede reconocer, tampoco puede ser reconocido por la Iglesia como válido, no puede ser administrado con la intención adecuada. Pero ellos mantienen las ordenaciones ${ }^{19}$.

Todas las Iglesias anglicanas mantienen en $\operatorname{común}^{20}$ : la Sagrada Escritura o Biblia, que comprende el Antiguo y Nuevo Testamento, como base de nuestra fe; el Credo de los Apóstoles y el del Concilio de Nicea como los enunciados básicos de la fe cristiana; el reconocimiento de los sacramentos del Bautismo y la Santa Comunión, y el episcopado histórico como tradición cristiana con los obispos ${ }^{21}$. El centro de la liturgia es la celebración de la Cena del Señor. En este ofrecimiento de oración y alabanza, es recordada la vida, la muerte, la resurrección y la ascensión de Cristo, por medio de la enseñanza de la Palabra de Dios y la celebración de los sacramentos ${ }^{22}$. La adoración se encuentra en el mismo corazón del anglicanismo. Su estilo puede variar desde la sencillez a la más elaborada liturgia tradicional ${ }^{23}$.Para la Iglesia Española Reformada Episcopal (IERE), el acercamiento directo a venerables textos litúrgicos con su gran fuerza espiritual; el uso de la lengua coloquial, cuando la Iglesia católica romana todavía seguía usando la lengua latina; el redescubrimiento entre algunos cristianos españoles de la Liturgia Mozárabe, de la Sagrada Escritura ${ }^{24}$.

\footnotetext{
${ }^{17}$ Cf. CHURCH House, Common Worship:Services and Prayers for the Church of England. Ordination Services London 2007, pp. 111-120.

${ }^{18}$ Cf. LEÓN XIII, “Bula Apostolicae curae”, en ASS 329 (1896-1897) 193-203; También LEÓN XIII, "Breve dirigido al cardenal Richard, arzobispo de Paris", en ASS 329 (1896-1897) 664-665.

${ }^{19}$ Cf. CHURCH HOUSE, Common Worship:Services and Prayers for the Church of England. Ordination Services, London 2007, pp. 155-169.

${ }^{20}$ Cf. L. L. MitCHELL, Pastoral and occasional liturgies, Meryland 2007, pp. 48-103.

${ }^{21} \mathrm{Cf}$. http://comunionanglicana.org/ Consultado el 18-03-2015.

${ }^{22}$ Cf. L. L. MITCHELL, Lent Holy Week easter and the Great Fifty Days, Meryland 2007, pp. 31-110.

$23 \quad$ Cf. http://www.anglicanos.org/web iglesia anglicana/g general/ga ca comunion anglicana.html Consultado el 18-03-2015.

${ }^{24}$ Cf. http://www.anglicanos.org/web iglesia_anglicana/g_general/ga_Im liturgia mozarabe.html Consultado el 18-03-2015.
} 
El arzobispo de Canterbury es el líder para la unidad de toda la Comunión Anglicana25. Reúne a los Primados y es el Presidente del Concilio Consultivo Anglicano. Tiene el título de Primado de toda Inglaterra, en reconocimiento de su primacía eclesiástica en Inglaterra. También está reconocido como la autoridad metropolita con respecto a todos los obispos y clero en las diócesis en el sur de Inglaterra. El de York posee la misma autoridad para las diócesis del norte de Inglaterra. Las relaciones Iglesia-Estado se simbolizan con los Lores Espirituales, que son los Arzobispos de Canterbury y York y otros veinticuatro obispos diocesanos, que tienen escaño en la Cámara de los Lores del Parlamento británico. Estos tienen el tratamiento de Su Gracia. Los obispos en general de Lord, los canónigos de Sir, los sacerdotes de Reverendo.

La autoridad suprema la ejerce el Sínodo General, es desde 1919, Church Assembly, compuesto por obispos y representantes del clero y laicos, elegidos al efecto, y sus resoluciones, cánones, las tienen que aprobar el Parlamento británico, sin enmendarlas, y recibir el consentimiento de la reina para ser consideradas parte de la legislación inglesa. La reina inaugura el Sínodo tras las elecciones que son cada cinco año ${ }^{26}$.Tiene también un poder judicial: las Cortes Eclesiásticas, que son parte del sistema judicial británico y tienen facultades especiales en lo que se refiere al cuidado de las iglesias y sus cementerios, así como a la disciplina del clero.

La Iglesia de Inglaterra (Church of England), es Iglesia cristiana mayoritaria en el Reino Unido, es la cabeza de la Comunidad anglicana, afiliación mundial de las Iglesias anglicana ${ }^{27}$. Al frente está el Arzobispo de Canterbury, que también es el Obispo Primado de Inglaterra y el Obispo Metropolitano de la Provincia de Canterbury. La designación de los obispos y la elección es algo más democrática y está supervisada por el comité de nombramientos (Crown Nominations Committee) y por el Primer Ministro, que actúa en nombre de la Rein ${ }^{28}$, aunque ella no interviene directamente en dicha designación.

\subsection{La Comunión anglicana}

En el orden jerárquico de la Iglesia anglicana existen tres grados de institución Divina, episcopado, sacerdocio y el diaconado. La cabeza de la Iglesia la ocupan los arzobispos, entre

\footnotetext{
${ }^{25}$ Cf. M. Devie, The Church of England, London, 2008, pp. 8-27

${ }^{26}$ Cf. TH. BANOSIUS, De politiâ civitatis Dei et hierarchiâ, Frankfort 1592; H. COLUMBUS, De angelicâ et humanâ hierarchiâ, Lyons 1647; D. PETAVIUS, De ecclesiasticâ hierarchiâ, París 1643; M. A. DE HALLER, De ecclesiasticâ hierarchiâ, Paris 1646; J. DARTIS, De ordinibus et dignitatibus ecclesiasticis, Paris 1648; J. MORINUS, Commentarium de sacris ecclesi ordinationibus, Antwerp 1695; J. BINER, Tractatus de Summâ Trinitate, fide catholicâ et hierarchiâ ecclesiasticâ, Augsburg 1765; A. G. ANDREUCCI, Hierarchia ecclesiastica in varias suas partes distributa, Rome 1766; E. T. A. HOFFMANN, De ecclesi catholic hierarchiâ tum ordinis quum jurisdictionis, Warsaw 1825; P. GASPARRI, Tractatus canonicus de sacrâ ordinatione, Paris 1893; S. B. SMITH, Elements of Ecclesiastical Law, New York 1881; E. L. TAUNTON, The Law of the Church, London 1906.

${ }^{27}$ Cf. M. Devie, The Church of England, London, 2008, pp. 28-41

${ }^{28}$ Cf. http://www.churchofengland.org/about-us/history.aspx Consultado el 15-12-2015.
} 
los que hay algunos que tienen el título de primados, estando a la cabeza de la provincia eclesiástica y pudiendo convocar una asamblea provincial o convocatoria. Por debajo, los obispos dirigen una diócesis auxiliados por un canciller o vicario general. Si la diócesis es suficientemente extensa existen sufragáneos u obispos auxiliares. También existen juntas y decanos de las catedrales, asambleas diocesanas, archidiáconos, decanos y pastore ${ }^{29}$.

El arzobispo de Canterbury disfruta cierto tipo de preeminencia de honor. Desde 1867, la conferencia de Lambeth se reúne cada diez años en Londres, a la cual son invitados todos los cuerpos obispales y anglicanos del mundo. En 1897 estableció un cuerpo central consultivo que se reorganizó en 1908, pero sin autoridad judicial. A pesar de muchos esfuerzos de unificar la Iglesia anglicana este objetivo no se ha conseguido ${ }^{30}$.

\subsection{Organización de la comunión Anglicana}

Todas las iglesias están en comunión con la sede de Canterbury, y por ello, el arzobispo de Canterbury, en su persona y ministerio, es el único foco de la unidad anglicana. El arzobispo convoca la Conferencia de Lambeth y la Reunión de Primados, y es presidente del Consejo Consultivo Anglicano (ACC): los tres instrumentos conciliares de comunión ${ }^{31}$. El llamado Cuadrilátero de Chicago-Lambeth se hizo público tras la Tercera Conferencia de Lambeth en 1888. En términos estrictos no es una definición de anglicanismo, sino un intento por definir las condiciones anglicanas para reunirse con otros grupos cristianos. De manera que, aunque es una definición resumida, por su propia naturaleza es tan amplia como los anglicanos pensaron que pudieran ser sin traicionar su identidad y patrimonio. Históricamente se derivó de un documento producido para la Convención General de la Iglesia Episcopal Americana en Chicago dos años antes ${ }^{32}$.El cuadrilátero expone los cuatro elementos esenciales de la fe cristiana y que son necesarios para la unión de las Iglesias:

1. Las Sagradas Escrituras del Antiguo y Nuevo Testamento, que "contienen todas las cosas necesarias para la salvación", como la regla y última norma de fe.

2. El Credo de los Apóstoles, como símbolo bautismal, y el Credo de Nicea, como declaración suficiente de la fe cristiana.

3. Los dos sacramentos ordenados por Cristo mismo, el Bautismo y la Cena del Señor, administrados con el uso indefectible de las palabras de institución de Cristo y los elementos ordenados por él.

\footnotetext{
${ }^{29}$ Cf. A. VAN Hove, "Hierarchy", en The Catholic Encyclopedia, Vol. VII, New York 1910.

${ }^{30}$ Cf. R. FrY, El anglicanismo en España, Madrid 1978.

${ }^{31} \mathrm{Cf}$. https://www.oikoumene.org/es/familias-de-iglesias/anglican-churches Consultado el 14-11-2016.

${ }^{32}$ Cf. http://www.iglesiaanglicana.org/libro/pagina17.htm Consultado el 14-11-2016.
} 
4. El episcopado histórico, adaptado localmente en los métodos de su administración a las diversas necesidades de las naciones y pueblos llamados por Dios a la unidad de su Iglesia ${ }^{33}$.

Dentro de la Comunión anglicana, las Iglesias que pertenecen al Consejo Mundial de las Iglesias (CMI) se encuentran las siguientes:

Iglesia Episcopal de Burundi; Iglesia de la Provincia de África Occidental; Iglesia en la Provincia de las Indias Occidentales; Iglesia Española Reformada Episcopal; Iglesia en Gales; Iglesia de Inglaterra; Iglesia Episcopal Escocesa; Iglesia Episcopal Anglicana del Brasil; Iglesia Anglicana de Kenia; Iglesia de la Provincia del Océano Índico; Iglesia de la Provincia de África Central; Iglesia de Nigeria (Comunión Anglicana); Iglesia Anglicana de Tanzania; Iglesia de Uganda; Iglesia de Irlanda; Iglesia Lusitana Católica; Iglesia Episcopal de Jerusalén y de Oriente Medio; Iglesia Anglicana del Canadá; Iglesia de Melanesia; Iglesia Anglicana de Australia; Comunión Anglicana en el Japón; Iglesia Anglicana de Corea; Iglesia de la Provincia de Myanmar (Birmania); Iglesia Episcopal en Filipinas; Iglesia Episcopal del Sudán; Iglesia Episcopal; Iglesia Anglicana de África Meridional; Provincia de la Iglesia Episcopal en Ruanda; Iglesia de Cristo en el Congo - Comunidad Anglicana en el Congo; Iglesia Anglicana en Aotearoa/Nueva Zelanda y Polinesia; Iglesia de Ceilán e Iglesia Anglicana de Sudamérica ${ }^{34}$.

\section{HISTORIA DE LA IGLESIA ESPAÑOLA REFORMADA EPISCOPAL}

La Iglesia Española Reformada Episcopal o Comunión Anglicana, es una Iglesia que predica al Cristo resucitado, trabaja para la extensión del Reino de Dios y proclama, y mantiene firmemente, la doctrina y el ministerio de la Iglesia Una, Santa, Católica, y Apostólica. La Iglesia forma parte de la Comunión Anglicana, compartiendo con ella tradiciones, orden, y plena comunión. Aunque con características propias, dada su condición nacional. Como tal Iglesia Española se siente continuadora de la antigua Iglesia de España, que gozó de independencia hasta el siglo $\mathrm{XI}$, en que fue sometida a la jerarquía y organización de la Iglesia de Roma ${ }^{35}$. La Iglesia fue organizada en 1868 por cristianos españoles disidentes de la Iglesia de Roma.

Al frente de ellos estaba don Juan Bautista Cabrera, que durante el reinado de Isabel II había estado exiliado en Gibraltar, y que al derrocamiento de la monarquía en 1868 fue autorizado por el general Prim a regresar a su patria y predicar el Evangelio libremente. En esta época comienzan a establecer congregaciones protestantes en las principales ciudades españolas.

\footnotetext{
${ }^{33}$ Cf. https://www.oikoumene.org/es/familias-de-iglesias/anglican-churches Consultado el 14-11-2016.

${ }^{34}$ Cf. M. DEVIE, The Church of England, London 2008, pp. 175-185.

35 Cf. http://www.anglicanos.org/web_iglesia_anglicana/g_general/g ini iglesia_protestante espana.html Consultado el 30-01-2016.
} 
Así, en el sínodo de 1880 se eligió obispo al reverendo Cabrera, y se decidió la adopción de la antigua liturgia Mozárabe. El obispo Cabrera fue consagrado en 1894 por tres obispos de la Iglesia de Irlanda de la Comunión Anglicana. La Iglesia siguió desarrollándose en España, pasando por diferentes etapas políticas, por difíciles momentos de intolerancia, persecución, represión e indiferencia, manteniendo su obra a pesar de estos y otros graves problemas, con el único objetivo de presentar el Evangelio de nuestro Señor y Salvador Jesucristo, para la gloria de Dios y la salvación de los hombres y mujeres de España ${ }^{36}$.

Es española. Su origen se debió a la decisión entregada de españoles, quienes habían ministrado en la Iglesia católica, pero de la que se separaron por disconformidad con la doctrina y la práctica de la misma.

Es reformada. Con lo que significa que ha rechazado, y rechaza, todas aquellas doctrinas y prácticas que son ajenas a la Sagrada Escritura o la Biblia, o son contrarias al contenido de la misma.

Es episcopal. Porque mantiene el triple orden del ministerio: obispos, presbíteros y diáconos, todo ello en la llamada sucesión apostólica. Tanto los obispos como los presbíteros y diáconos pueden ser casados.

Es litúrgica. Sus oficios siguen la liturgia Mozárabe, rito que fue de la Iglesia de España hasta el siglo XI, en que fue sustituido a la fuerza por el Rito romano.

Es sinodal. Los Sínodos se celebran periódicamente, cada dos años, y lo forman, en partes iguales, los ministros y miembros de las iglesias locales, elegidos en sus congregaciones. Cualquier miembro de la IERE, hombre o mujer, puede ser elegido y ser Delegado al Sínodo, en el que participará con voz y voto.

Es sacramental, pues administra el Bautismo y la Cena del Señor como Sacramentos ordenados por nuestro Señor Jesucristo en el Evangelio ${ }^{37}$.

\subsection{Fundamentos de la Fe en la Iglesia Española Reformada Episcopal}

La Iglesia Española Reformada Episcopal ${ }^{38}$ reconoce tres fundamentos de la fe que son los siguientes:

A. La Santa Biblia: Es la fuente y autoridad de toda doctrina. La Iglesia Episcopal cree que las Escrituras contienen toda la doctrina necesaria para la salvación, y que nada

\footnotetext{
36 Cf. http://www.anglicanos.org/web iglesia anglicana/g general/g qs iglesia espanola reformada.html Consultado el 30-01-2016.

37 Cf. http://www.anglicanos.org/web_iglesia_anglicana/g_general/g_qs_iglesia_espanola_reformada.html Consultado el 30-01-2016.

${ }^{38}$ Cf. Iglesia Española Reformada Episcopal, Declaración de Doctrina. Aprobada en el Sínodo del año 1883, Madrid 1975
} 
que no esté explícita o implícitamente en ellas es considerado como artículo de fe, ni necesario para la salvación. Tanto el Antiguo como el Nuevo Testamento contienen la Revelación de Dios a los hombres, y son la Palabra de Dios que proclama a Jesús como Dios y hombre y como el Mesías, el Cristo.

B. La tradición: Nos ayuda a interpretar la Escritura y se subordina a ella. Nos permite compartir las experiencias de los primeros cristianos y de los fieles de todas las épocas. Preserva himnos, plegarias, etc., que mantienen viva nuestra fe y la fortalecen. Por su continuidad y consistencia, la tradición nos ayuda a preservar las verdades esenciales mediante la liturgia.

C. La razón: La Iglesia Episcopal fomenta en sus miembros el uso de la razón para explorar y comprender las obras de Dios y para tomar decisiones responsables bajo la guía de la Escritura, o recibiendo el consejo de un ministro ordenado, o en respuesta a la oración sincera.

\section{Los credos}

Son símbolos de la fe cristiana que expresan claramente nuestra fe en la Santísima Trinidad. La Iglesia Española Reformada Episcopal acepta los tres credos de la Iglesia primitiva:

\section{Principios Básicos}

Principios básicos de la fe cristiana son ${ }^{39}$

A. La Santísima Trinidad: Dios se manifiesta al hombre en tres personas: Dios Padre Creador: Dios es amor, y también es justo, infinito, todopoderoso, bueno; tiene un propósito para el hombre revelado por sus propias vías. Dios Hijo Redentor: Dios hecho hombre para nuestra salvación. Su vida, muerte y resurrección nos liberan de las limitaciones del pecado y de la muerte. Dios Espíritu Santo Santificador: Actúa dentro del hombre, da vida a la Iglesia y nos capacita para asemejarnos a Jesucristo.

B. La Salvación: Significa el fin de nuestra separación de Dios y el comienzo de una vida nueva acorde con su voluntad. Se consigue por el hombre únicamente a través del sacrificio de Cristo. El hombre es pecador, como todos los hombres, y como consecuencia de esto se encuentra separado y destituido de la gloria de Dios. Jesucristo es la única provisión de Dios para el pecador: es el único mediador entre Dios y el ser humano. Gracias a que Él murió por nuestros pecados, podemos ser perdonados y podemos volver a tener comunión con Dios. Para ello debemos

\footnotetext{
${ }^{39}$ Cf. Iglesia Española Reformada Episcopal, Liturgia. Oficios Divinos y administración de los sacramentos y otros ritos, Madrid 1954, pp. 595-605; J. B. Cabrera, Liturgia de la Iglesia Española Reformada, Madrid 1889; A. Andrés Puchades, "La Iglesia Española Reformada Episcopal”, en J. García Hernando (Dir.), Pluralismo religioso I. Confesiones cristianas, Madrid 1992, pp. 105-152.
} 
arrepentirnos de nuestros pecados, o sea, cambiar de actitud y volvernos a Él. Debemos recibir a Cristo por fe, mediante una invitación personal, aceptándolo como nuestro salvador y dejándolo que Él sea el Señor de nuestra vida. Así podremos conocer y experimentar el amor y el propósito de Dios para nuestra vida. Somos llamados a seguir a Jesucristo en la confraternidad de su Iglesia ${ }^{40}$. Una Iglesia que aparece con los signos de una estructura sumamente democrática, asentada en cuerpo legal del Sínodo, que es la máxima autoridad de dicha Iglesia, donde se encuentran todos representados: laicos, clero y obispos.

C. La Iglesia: Es el pueblo de Dios, como un cuerpo cuya cabeza es Cristo; todos los bautizados son sus miembros. La Iglesia es:

- Una: Un cuerpo con una cabeza (Cristo).

- Santa: El Espíritu Santo mora en ella y en sus miembros.

- Católica: Universal. Mantiene la fe para todos los lugares y todas las gentes.

- Apostólica: Es continuidad de la enseñanza y hermandad de los apóstoles.

D. El culto: Es una respuesta gozosa al amor de Dios. Expresa el gozo de la salvación y nos da una oportunidad de adorar a Dios y recibir de Él fortaleza y perdón. De este modo compartimos nuestra fe con otros creyentes. El culto episcopal es litúrgico, pues se remonta a la antigüedad y se desarrolla hasta la actualidad. Se suelen utilizar la Sagrada Escritura, que se lee regularmente a través del año eclesiástico, el libro de liturgia o de oración, que contiene los órdenes del culto ordinario y de cultos especiales y el himnario, que contiene himnos y cánticos. Los cultos pueden ser desde simples hasta ceremoniosos y solemnes. El sentido litúrgico ha permanecido en ellos ${ }^{41}$.

\section{Sacramentos}

Un sacramento es un signo externo y visible de una gracia interna e invisible. Hay dos sacramentos instituidos por Cristo, medios de gracia esenciales para todo cristiano:

1. Bautismo: Es la puerta de entrada a la familia de Dios. Se administra una sola vez a cada persona (generalmente en la niñez). Se realiza con agua, simbolizando la limpieza del pecado, y se invoca a la Santísima Trinidad. El don interior y espiritual es

\footnotetext{
${ }^{40}$ Cf. E. H. BRownE, Exposición histórica y doctrinal de los treinta y nueve artículos de la Iglesia Anglicana. Parte 5. Exposición de la doctrina de la Iglesia Anglicana acerca de los santos sacramentos, Londres 1875

${ }^{41}$ Cf. C. LÓPEZ LOZANO, Liturgias no romanas en lengua castellana durante los siglos XVI a XX, Salamanca 1990.
} 
la unión con Cristo en su muerte y resurrección, el perdón de los pecados y un nuevo nacimiento a la familia de Dios, la Iglesia ${ }^{42}$.

2. Santa Cena: Se trata de la conmemoración y acción de gracias por la muerte y resurrección de Cristo. Se utilizan el pan y el vino. El cuerpo de Cristo se da, se toma y se come de un modo celestial y espiritual, y el medio por el cual se recibe y se come es la fe. Por el sacramento de la Eucaristía, los miembros de la Iglesia se ofrecen a sí mismos a Dios en arrepentimiento, amor y fe, recuerdan su muerte, testifican su sacrificio y renuevan su esperanza en la comida celestial. La IERE practica una política de comunión abierta a los miembros comulgantes de las demás iglesias cristianas ${ }^{43}$. Además, hay cinco ritos sacramentales que se desarrollaron en la Iglesia bajo la inspiración del Espíritu Santo, pero que no tienen la misma naturaleza que los anteriores. No fueron ordenados por Cristo, y no se aplican a todos los fieles. Los ritos sacramentales son:

A. Confirmación: Servicio por el cual, mediante la oración e imposición de manos por el obispo, y con la acción del Espíritu Santo, se renueva y fortalece el compromiso con Cristo hecho en el bautismo.

B. Matrimonio: Mediante este signo, el hombre y la mujer, entrando en unión para toda la vida, hacen sus promesas ante Dios y piden su gracia y bendición para cumplirlas.

C. Reconciliación del penitente: Reconocimiento y confesión a Dios de los pecados, hecha libre y voluntariamente en presencia de un ministro, y con un sincero deseo de cambiar de actitud. Por medio de la absolución, el ministro afirma el perdón de Dios y la reconciliación del pecador.

D. Orden: Mediante este rito, se consagran cristianos al servicio de Dios. Reciben el poder y la gracia que les ayuda a dedicar sus vidas al bien de la comunidad enseñando, administrando los sacramentos y gobernando la Iglesia.

E. Unción de los enfermos: Servicio por el cual se da la gracia de Dios para la sanidad física y espiritual en respuesta a la fe y oración. Se muestra con la imposición de manos o por la unción con aceite.

F. El Ministerio: El triple ministerio es el centro de la estructura de la Iglesia, que así expresa su unidad ${ }^{44}$ :

\footnotetext{
${ }^{42}$ Cf. A. Andrés Puchades, "La Iglesia Española Reformada Episcopal”, en J. García Hernando (Dir.), Pluralismo religioso I. Confesiones cristianas, Madrid 1992, pp. 135-136.

${ }^{43}$ Cf. A. Andrés Puchades, "La Iglesia Española Reformada Episcopal”, en J. García Hernando (Dir.), Pluralismo religioso I. Confesiones cristianas, Madrid 1992, pp. 136-137.

${ }^{44}$ Cf. ChurCh House, Visual Liturgy Live, London 2006.
} 
- Episcopado: El obispo es el vigilante espiritual de una diócesis (grupo de parroquias y misiones) que lo ha elegido para ese oficio. Actúa como gobernante de la Iglesia, consejero del clero; tiene el poder de ordenar presbíteros y diáconos, consagrar a otros obispos y administrar la confirmación. Los obispos son los sucesores de los apóstoles, por lo que se dice que la Iglesia sigue la línea de sucesión apostólica. Cuando se trata de un obispo de una provincia (grupo de diócesis) se suele hablar de arzobispo.

- Presbiterado: El presbítero o pastor es el que dirige la parroquia. Sus actividades incluyen aspectos pastorales, espirituales y educativos; enseña y bautiza, celebra la Santa Comunión, pronuncia la absolución y la bendición en el nombre de Dios y realiza otras muchas funciones ${ }^{45}$.

- Diaconado: El diácono asiste al presbítero en su trabajo parroquial, o ministra bajo la supervisión del obispo en una misión o parroquia no organizada46. Hay que tener en cuenta que existen otras realidades.

Aparte de estos ministerios ordenados, pueden existir en la Iglesia agrupaciones con finalidades especiales de trabajo, como grupos de mujeres, hombres, jóvenes... También se potencia el trabajo de los laicos en los ministerios de instrucción a los niños, evangelización, acción social, mayordomía... Existen en la Comunión Anglicana órdenes religiosas que generalmente realizan funciones en el campo social, médico o educativo, además del religioso ${ }^{47}$.

Para el Anglicanismo, su vinculación y su mismo origen estuvo en el enfrentamiento de Enrique VIII con el papado a causa del divorcio con Catalina de Aragón. Será durante los siglos XIX y comienzos del XX, cuando aparece con gran intensidad, en el seno de la Iglesia de Inglaterra un movimiento de acercamiento a la Iglesia católica por un grupo de hombres de fuerte talla y girará en intrépido interés por la unión de todas las Iglesias ${ }^{48}$.

Las Iglesias no pueden entrar en unión mutua si no es muriendo a su propia existencia como Iglesias separadas. No deben realizarlo de esta manera a no ser que mantengan la plena seguridad de que Dios mismo las llama a su muerte o desaparición para llegar a una mayor plenitud que es la resurrección. Es positivo esperar que las Iglesias anglicanas no se agarren indebida o egoístamente a su vivencia anglicana con suma persistencia en la separación. Su pervivencia se mantiene como objetivo entre muchos

\footnotetext{
${ }^{45} \mathrm{Cf}$. CHURCH HOUSE, Common Worship:Services and Prayers for the Church of England. Ordination Services, London 2007, pp.152-154; L. L. MITCHELL, Pastoral and occasional liturgies, Meryland 2007, pp. 104-129; Cf. L. L. MITCHELL, Lent Holy Week easter and the Great Fifty Days, Meryland 2007, pp. 3-28.

${ }^{46}$ Cf. A. Andrés Puchades, "La Iglesia Española Reformada Episcopal”, en J. García Hernando (DiR.), Pluralismo religioso I. Confesiones cristianas, Madrid 1992, pp. 140-143.

47 Cf. http://www.anglicanos.org/web iglesia anglicana/g general/g qs iglesia espanola reformada.html Consultado el 30-01-2016.

${ }^{48}$ Cf. C. LóPEZ LOZANO, Precedentes de la Iglesia Española Reformada Episcopal, Madrid 1991, pp. 107-131.
} 
sectores, más allá que muchos de sus miembros, hayan pedido su incorporación a la Iglesia católica. De todas maneras, la unión de todo el pueblo de Dios, debe seguir permaneciendo en todos sus hijos, más allá de su pertenencia a las diversas Iglesias ${ }^{49}$.

\section{PROTOCOLO Y CEREMONIAL DE LAS IGLESIAS REFORMADAS}

E luteranismo apareció el 31 de octubre de 1517, fecha en que Lutero fijó sus tesis a la puerta de la iglesia del castillo de Wittenberg. Aunque él no se separó de la Iglesia católica hasta tres años después, ya entonces se había acercado significativamente a sus posiciones posteriores acerca del plan de salvación. Las nuevas enseñanzas, sin embargo, sufrieron grandes cambios después que Lutero retornó de Wartburgo en 1521. Antes de su muerte, el 18 de febrero de 1546, sus enseñanzas ya habían sido propagadas en muchos territorios de Alemania, de Polonia, en las provincias bálticas, Hungría, Transilvania, Los Países Bajos, Dinamarca y Escandinavia.

El luteranismo se expandió desde esos países europeos y llegó al Nuevo Mundo. En los Estados Unidos es una de las denominaciones protestantes más importantes. El término luteranismo fue acuñado por sus opositores durante la disputa de Leipzig en 1519, y después recibió prevalencia universal. Lutero prefería el nombre de evangélica, y actualmente se conoce como Iglesia Evangélica Luterana. En Alemania, donde los reformadores y los luteranos se reunieron, desde 1817, se ha abandonado el título de luterana, y se le nombra Evangélica o Evangélica Unida.

En el caso de los calvinistas han suprimido prácticamente todas ceremonias; excepcionalmente han mantenido el Bautismo y la Cena, eliminando todos los ritos anteriores a la Reforma. No siguen las líneas de la liturgia reformada. Los luteranos han conservado una liturgia histórica proveniente de la Misa previa al Concilio de Trento y es más conservadora que la católica. No obstante, se puede apreciar cierta similitud en los cultos o reuniones con las formas contemporáneas de las Iglesias evangélicas de hoy en día. Una característica que se conserva del catolicismo es la indumentaria clerical que emplean los líderes espirituales en los actos y celebraciones litúrgicas, que es parecida a la de la Iglesia católica, tanto en el caso de los luteranos como los anglicanos.

El ministro que oficia vestirá la túnica o toga blanca que en todo tiempo usó la Iglesia; y la banda o estola, puesta sobre el hombro izquierdo y recogida al lado derecho, en los diáconos, y puesta sobre los dos hombros y colgando por delante, en los presbíteros. Queda excluido cualquier otro ornamento o vestidura eclesiástica, a no ser la toga negra, que puede usarse para la predicación y para el oficio de sepultura o exequias. También pueden oficiar varios ministros a la vez, si hay oportunidad para ello, distribuyéndose las diversas partes del culto. Cuando en los oficios se asigna alguna parte expresamente al diácono, se entiende

\footnotetext{
${ }^{49}$ Cf. S. NeILL, El anglicanismo, Madrid 1986, p. 411.
} 
que puede leerla cualquier otro ministro, e incluso el mismo oficiante o que preside la celebración ${ }^{50}$.

Los anglicanos, más moderados, son los que menos se separaron de esas tradiciones. Estos han pedido la entrada en la Iglesia católica romana, por lo que el 4 de noviembre de 2009, el papa Benedicto XVI publicó la Constitución apostólica Anglicanorum coetibus ${ }^{51}$, que ofrece una normativa general que regule la institución y la vida de aquellos fieles anglo católicos que desean entrar corporativamente en la comunión plena con la Iglesia Católica romana. Los protestantes conservaron de las ceremonias las reuniones de religión y el canto, el Bautismo, que es una purificación o una lustración, la Cena, que es una comida religiosa, las fiestas, los ayunos solemnes, la imposición de las manos, las exequias a los difuntos. El protocolo que se sigue según sus ceremoniales guarda gran parecido a los ritos del ceremonial católico. La belleza y perfección formal del ceremonial de la Iglesia, en sus celebraciones, es un reflejo más de su importancia desde hace veinte siglos. Que su liturgia se haya enriquecido desde entonces no ha hecho sino reafirmar la realidad de sus signos y ensalzar su importancia ante el pueblo cristiano. No hace falta más que ver una celebración desde el Santo Padre en cualquiera de las Basílicas Vaticanas, como otra de un obispo o presbítero en sus catedrales o iglesias respectivas.

El protocolo que afecta esencialmente al modo de estar y comportarse, en cada momento, supone una especial y delicada expresión y función de aquello que exigen las formas, el estilo y el modo propio de cada Iglesia ${ }^{52}$ como es el saludo, la visita de autoridades, tomas de posesión y provisión de oficios, la disposición que debe guardarse en cada celebración con la asistencia de otros miembros de distintas Iglesias y Comunidades eclesiales, sobre todo en la asistencia a las ceremonias con culto público, de diversas autoridades religiosas y civiles. Se puede apreciar mucho mejor la recogida, con cierta preponderancia, por la Iglesia católica. El protocolo eclesiástico en sí, es decir, al conjunto de técnicas protocolarias que cualquier persona debería tener en cuenta para la organización de una ceremonia propia de cada Iglesia, es fundamental para comprender su significado y trascendencia. La división entre católicos y protestantes era, en parte, una diferencia acerca de las creencias con respecto a la lengua que se utilizaba en la liturgia.

Una misa en latín, sería algo que uno principalmente ve y escucha; un servicio religioso en lengua vernácula, sería otro que se suponía que habría de entender y participar en él. La revisión de la liturgia romana mantuvo el latín, para el uso de toda la Iglesia occidental, o de rito romano y reiteró su oposición a los reformadores. De esta manera todo el movimiento litúrgico, que comenzó como un nuevo intento de restaurar la liturgia a sus antiguos principios, dio lugar a cambios que han afectado tanto a los católicos romanos y protestantes, en sentido bien divergente. Las Iglesias de amplia tradición luterana han sido fuertemente influenciadas por el movimiento de cambio en su indumentaria litúrgica y en

\footnotetext{
${ }^{50} \mathrm{Cf}$. Liturgia de la Iglesia Española Reformada Episcopal, Madrid 1954, p. XVI.

${ }^{51}$ Cf. BenedICTO XVI, “Constitución apostólica Anglicanorum coetibus”, en AAS 101 (2009) 987-990.

${ }^{52}$ Cf. Liturgia de la Iglesia Española Reformada Episcopal, Madrid 1954, pp. IX-X.
} 
los rituales. Vestidos de negro durante mucho tiempo han sido sustituidos por las vestiduras católicas tradicionales. Sus clérigos han ido adoptando muchos de los símbolos litúrgicos tradicionales, como son el signo de la cruz, el incienso y la casulla completa, que se han recuperado haciéndose más común su uso en los últimos años. Mientras que se ha dado un mayor margen de libertad en el estilo ejercido por las distintas congregaciones individuales, se puede afirmar que el estilo general en los temas como la adoración litúrgica, incluyendo la vestimenta, los adornos del altar, acentuándose una vuelta general de muchas prácticas formales tradicionales, lo que ha llevado a un proceso de mayor cercanía a los estilos de la Iglesia católica romana más formal53 y las tradiciones más puramente anglicanas. Sería en el siglo XVI, cuando las Iglesias surgidas de la Reforma desecharon los colores para los tiempos litúrgicos como un complemento del culto. Serían los calvinistas lo más opuestos a ello que sólo aceptaron la toga negra que se pone sobre la ropa de color oscuro que se utiliza de calle. Con el correr de los tiempos muchas de las Iglesias protestantes reintrodujeron progresivamente el color, como los luteranos que con sus propios esquemas de colores han llegado a sustituir el amarillo por el verde54.Entre las ramas protestantes se encuentran las siguientes: luteranos, anglicanos, calvinistas, metodistas, bautistas y pentecostales. Primero, se omite el canon, con sus oraciones sacrificiales; se recoge la doctrina de la presencia real de Cristo, pero no el concepto de sacrificio eucarístico. Segundo, todo el culto se lleva a cabo en lengua vernácula. Tercero, el sermón u homilía es considerado la parte integral e indispensable del culto. Cuarto, el canto de himnos por la congregación es recogido como una parte importante del rito; es decir, mientras que en el culto católico y anglicano se pueden cantar himnos, en la eucaristía luterana es indispensable hacerlo.

En la tradición luterana no hay la exigencia de una adecuación o unificación ritual, de ahí el resultado de la gran divergencia entre las Iglesias escandinavas, más conservadoras, y las alemanas, donde se ha modificado mucho la herencia litúrgica del luteranismo primitivo. Los escandinavos protestantes, por ejemplo, han conservado el altar con sus crucifijos y velas y la casulla para el celebrante, elementos que fueron abandonados por las otras Iglesias protestantes. Por tanto, la renovación litúrgica es la consecuencia natural de una renovación teológica; la renovación litúrgica debe pasar por la incorporación de nuestros valores culturales; la renovación litúrgica debe promover la participación y sea el culto de toda la comunidad. Las posturas y gestos, así como los ademanes en la oración son las adecuadas manifestaciones y participaciones corporales de la oración interna. La liturgia necesita del uso de signos sensibles y formas externas: palabras, cantos, símbolos, gestos... que excitan y son expresión de la devoción interna y, al mismo tiempo, relacionan a la misma oración con los actos internos ${ }^{55}$.

\footnotetext{
${ }^{53}$ Cf. L. EISENHOFER, Compendio de Liturgia Católica, Barcelona 1947.

54 Cf. http://www.buzoncatolico.es/formacion/catolicismoyreligion/colores-en-la-liturgia-de-la-iglesia.html Consultado el 18-03-2015.

${ }^{55}$ Cf. J. BAUtISTA CABreRA, Manual de Doctrina y Controversia, Madrid 1900; P. García RuBıo, La Iglesia Evangélica Española, Iglesia protestante: 125 años de vida y testimonio, Barcelona 1994.
} 


\section{IGLESIA EVANGÉLICA ESPAÑOLA}

La Iglesia Evangélica española, fundada en 1869, es miembro del Consejo Mundial de Iglesias, de la Conferencia de Iglesias Europeas, de la Conferencia de Iglesias Protestantes de los Países Latinos de Europa, de la Comunión Mundial de Iglesias Reformadas y del Consejo Mundial Metodista. La Historia es el resultado de hechos y acontecimientos, estos se transforman en corrientes y contracorrientes, acciones e interacciones, dando lugar, a través de ellas, a nuevos hechos y nuevos acontecimientos. La Reforma protestante del siglo XVI surge del encuentro entre la Palabra, y el Espíritu, surge con el Renacimiento: regreso a las fuentes y nueva lectura de los textos. Otros factores políticos y tecnológicos la impulsarán hacia el horizonte de las naciones. En su desigual avance entre los pueblos se encuentra, con nuevos acontecimientos, estos, a su vez, fruto de la Historia ${ }^{56}$.

\section{1. Historia de la Iglesia Evangélica española}

A finales del siglo XVIII y principios del XIX se da una fuerte expansión de las misiones protestantes, favorecida por la revolución industrial naciente. La Iglesia Evangélica española, cuyas fuentes remontan a la Reforma del siglo XVI, echa sus raíces en el trabajo misionero que nace en el seno de los pietismos del siglo XVIII y se inspira de ellos. La Iglesia Evangélica española se define a sí misma como una comunión de congregaciones integradas progresivamente desde 1869 hasta 1955. Todas ellas se han dotado de una confesión de fe común, y desarrollan su testimonio y misión bajo una estructura sinodal. A lo largo del siglo XIX se consolida como una unión de comunidades con estructura sinodal. Estas congregaciones vienen de diferentes tradiciones protestantes tomadas de aquellas misiones extranjeras que impulsaron su establecimiento a lo largo de la primera mitad del siglo XIX (reformada, presbiteriana, luterana, metodista, congregacionalista) y su crecimiento a partir de 1868, con el triunfo de la Revolución Liberal. El núcleo original lo forman congregaciones nacidas en medio de la intolerancia y en la clandestinidad, fundadas como fruto de la labor y el ministerio de pastores tales como Antonio Vallespinosa (1833-1997), el catalán Francisco de Paula Ruet (1826-1878), el andaluz, Manuel Matamoros (1834-1866), el alicantino Juan Bautista Cabrera (1837-1916), el catalán Francisco Albricias (1856-1934) todos ellos conocieron persecución y exilio, en Gibraltar y en otros países europeos, recibiendo en ellos la formación teológica que les capacitó para el desarrollo de su misión y ministerio. En 1869, en Sevilla, se reúne una asamblea general formada por delegados de distintas congregaciones entonces existentes en el territorio español y crean la Iglesia Reformada Española, que en 1872 adopta el sistema presbiteriano tomando el nombre de Iglesia Cristiana Española. Federico Fliedner, primer misionero alemán que viene a España, llega en el año 1869, apoyado por la Obra de las Diaconisas de Kaiserswerth, fundada por su padre, Teodoro, en 1828. Con la creación de escuelas, centros de atención a los más necesitados, librerías, Fliedner es el fundador de una obra social vinculada a la Iglesia Evangélica Española. La Fundación que hoy lleva su nombre, fiel a su talante, desarrolla su misión de

\footnotetext{
${ }^{56}$ Cf. http://www.iee-es.org/ Consultado el 30-01-2016.
} 
enseñanza, de formación teológica, acción social y cultural al servicio del protestantismo español en particular y la sociedad española en general. En 1886 se celebra en Madrid la X Asamblea de la Iglesia Cristiana Española formada por representantes de sus comunidades en Madrid, Sevilla, Córdoba, Granada, Jerez, Isla de san Fernando, Málaga, Reus, Camuñas, Mocejón, Cartagena, Cádiz y Huelva, y las misiones de Utrera y Villafranca de Córdoba, todas ellas de tradición presbiteriana ${ }^{57}$. La Unión Ibero-Evangélica, que agrupaba congregaciones de tipo congregacionalista en Santander, Bilbao, San Sebastián, Logroño, Pradejón y Zaragoza, con varias misiones, decidió unirse a la Iglesia Cristiana española que, con este motivo, cambió provisionalmente su nombre por el de Iglesia Evangélica española, adoptando, también provisionalmente como bases la confesión de fe y la disciplina de la Iglesia Cristiana española. Este grupo de congregaciones constituido a partir del ministerio desarrollado por los hermanos Thomas y William Gulick sostenidos por la American Board, de tradición congregacionalista. A estas congregaciones se unieron las comunidades que surgieron como resultado de la Misión del Alto Aragón, desarrollada por el pastor francés Albert Cadier, entre 1906 y 1911. En 1901, Alice Gordon Gulick funda el Instituto Internacional, en Madrid, institución dedicada a la promoción de la educación y la emancipación social de la mujer. Dicho instituto se desarrolló paralelamente a la Institución Libre de Enseñanza (1876) que propugnaba la libertad de cátedra y una enseñanza no sometida a los dogmas oficiales en religión, política o moral. En 1955 la Iglesia Metodista Española decide unirse a la Iglesia Evangélica Española, para lo cual el Sínodo de 1954 aprueba una versión revisada de su Confesión de fe y de su reglamento. La Iglesia Metodista aporta a la Iglesia unida sus comunidades en Cataluña y en las Islas Baleares. La Iglesia Metodista había llegado a Cataluña y Baleares en 1869, creando su primera comunidad el 10 de septiembre de 1871 . Fueron misioneros ingleses los que realizaron los primeros trabajos de evangelización, cabe destacar a William T. Brown, fundador de las primeras escuelas y comunidades entre 1869 y 1874, y los reverendos Franklin G. Smith entre 1888 y 1916, y William Lord entre 1916 y 1924; pero muy pronto fueron seguidos por obreros españoles que establecieron nuevas escuelas e iglesias. En el momento de la unión, la aportación metodista fue en Cataluña de las comunidades antiguas de Barcelona y Rubí, a las que se añadieron posteriormente las nuevas comunidades de I'Hospitalet de Llobregat, Santa Coloma de Gramenet y La Llagosta. En las Baleares ingresaron en la IEE las iglesias de Palma de Mallorca, Capdepera, Mahón, Es Castell y misiones. Esto hizo que la IEE, que estaba muy poco representada en Cataluña y Baleares, recibiera ahora un fuerte impulso.

También la Iglesia Metodista (USA) sostuvo varias iglesias y colegios en España antes de la guerra civil, entre ellas las comunidades de Alicante, con su muy conocida Escuela Modelo y Sevilla. La Iglesia Evangélica española, como iglesia unida, pertenece a dos de las grandes familias protestantes, agrupadas hoy en sendos organismos: la Alianza Reformada Mundial y El Consejo Mundial Metodista, es miembro del Consejo Mundial de Iglesias desde su fundación en $1948^{58}$. Su presente se enriquece de las corrientes teológicas del pasado. Es

\footnotetext{
${ }^{57}$ Cf. D. VIDAl RegalizA, Nosotros, los protestantes españoles, Madrid 1969; E. G. LeONARD, Historia General del Protestantismo, Barcelona 1967.

${ }^{58}$ Cf. R. TAIBO, Una Iglesia centenaria pero desconocida, Madrid 1980.
} 
el resultado de los mejores materiales que cada una de ellas ha ido dejando a la Iglesia a largo de la historia ${ }^{59}$.

\section{2. Fundamentos de fe en la Iglesia Evangélica española}

La confesión de fe evangélica posee los siguientes artículos:

\section{Artículo I: De las Sagradas Escrituras}

Creemos y testificamos que las Sagradas Escrituras son la Palabra de Dios, mediante la cual Dios ha hablado y habla al hombre y le hablará hasta el final de los tiempos; revelándole su santa voluntad y ofreciéndole eterna salvación. Inspiradas por Dios mismo, están libres de error en todo cuanto atañe a la salvación del hombre y nada es inútil en ellas, ya que toda Escritura, dada por el Espíritu de Dios, es útil para enseñar, para redargüir, para corregir, para instruir en justicia. Como testimonio profético y apostólico divinamente inspirado, las Sagradas Escrituras son ellas mismas su verdadero intérprete y comprensibles al hombre por obra del Espíritu Santo.

El conjunto de las Sagradas Escrituras es la Biblia, la cual comprende los siguientes libros, llamados canónicos: Antiguo Testamento: el Génesis, el Éxodo, el Levítico, los Números, el Deuteronomio, Josué, Jueces. Ruth, 1 y 2 de Samuel, 1 y 2 de Reyes, 1 y 2 de Crónicas, Esdras, Nehemías, Ester; Job, Salmos, Proverbios, Eclesiastés, Cantar de los Cantares; Isaías, Jeremías, Lamentaciones, Ezequiel, Daniel, Oseas, Joel, Amós, Abdías, Jonás, Miqueas. Nahúm, Habacuc, Sofonías, Ageo, Zacarías y Malaquías. Nuevo Testamento: Evangelio según Mateo, Marcos, Lucas y Juan; Hechos de los Apóstoles; Epístolas de Pablo a los Romanos, 1a y 2a a los Corintios, a los Gálatas, a los Efesios, a los Filipenses, a los Colosenses, 1a y 2a a los Tesalonicenses, 1a y 2a a Timoteo, a Tito, a Filemón, Epístola a los Hebreos, Epístola de Santiago, Epístolas 1a y 2a de Pedro, Epístolas 1aㅡ 2 a y 3 a de Juan, Epístolas de Judas y el Apocalipsis de Juan.

Fuera de la Biblia no reconocemos ninguna regla infalible en cuestiones de fe y moral $^{60}$. Los libros llamados apócrifos, incorporados a algunas ediciones de la Biblia, carecen de carácter normativo absoluto. Asimismo, no reconocemos carácter autoritativo, independiente de las Sagradas Escrituras, a la llamada Tradición Eclesiástica, o sea, al conjunto de interpretaciones de la Sagrada Escritura en la Iglesia a través de los tiempos ${ }^{61}$.

\footnotetext{
${ }^{59}$ Cf. http://www.iee-es.org/breve-aproximacion-historica-a-la-iglesia-evangelica-espanola/ Consultado el 3001-2016.

${ }^{60}$ Cf. J. L. López Aranguren, El protestantismo y la moral, Madrid 1954; J. L. López Aranguren, Catolicismo y protestantismo como formas de existencia, Madrid 1963; P. JOHnSON, Historia del cristianismo, México 2006.

${ }^{61}$ Cf. A. Gounelle, Los grandes principios del protestantismo, Puebla (México) 2008; J. TORRUBIANO RIPOLL, Consecuencias históricas y sociales de la Reforma, Madrid 1928.
} 


\section{Artículo II: De Dios}

Creemos y testificamos que hay un solo Dios eterno, verdadero, personal, santo, justo y misericordioso, el mismo que confiesan los Símbolos llamados Apostólico, Niceno y Atanasiano $^{62}$; el mismo revelado en las Sagradas Escrituras como Creador, Gobernador y Sustentador de todo cuanto existe, lo visible y lo invisible; el mismo en tres personas: Dios Padre, Dios Hijo y Dios Espíritu Santo, o sea, la Santísima Trinidad, solamente a la cual debemos adoración y honra y gloria en vida y en muerte.

\section{Artículo III: De la Providencia}

Creemos y testificamos que al Dios Todopoderoso le plugo desde un principio sustentar, gobernar y mantener al hombre en sujeción a Él, mediante su Providencia y asimismo a todas las criaturas. También están sujetos a la Providencia divina, los elementos y todas las circunstancias que rodean la vida del hombre, de manera que éste puede confiar en suerte y desgracia, abundancia y escasez, felicidades y calamidades en que no depende de la casualidad, ni del destino ciego, sino que es objeto.

\section{Artículo IV: Del hombre}

Creemos y testificamos que Dios creó al hombre a su imagen y semejanza, diferenciándole así de todas las demás criaturas visibles e invisibles y dotándole de conocimiento, justicia y santidad, a fin de que viviera en comunión con su Creador, y para que, sin dejar de ser criatura sujeta a Dios, se enseñorease de la Creación visible y procrease el género humano; y todo ello había de ser para gloria del Creador. Con estos fines, también dotó Dios al hombre de libertad, señalándole, al mismo tiempo, que quedaba sujeto a la voluntad del Creador, su Señor.

\section{Artículo V: De la caída del hombre}

Creemos y testificamos que el hombre, al pretender igualarse orgullosamente a su Creador mediante el hecho de la desobediencia, perdió la justicia original que poseía, quedando quebrantada por el pecado su comunión con Dios. Aunque como criatura no perdió del todo "su imagen y semejanza de Dios", esta imagen y semejanza resultó para siempre borrosa y corrompida. De aquí que desde la Caída o Pecado original todos los hombres nazcan inclinados al mal, incapaces por sí mismos de hacer la voluntad de Dios, impotentes para salvarse por propio esfuerzo y merecedores, por sus pecados, de la muerte eterna, por carecer de verdadera comunión con Dios.

\footnotetext{
${ }^{62}$ Se trata de Símbolo Pseudo-atanasiano "Quicumque". Atribuido a Atanasio de Alejandría y al papa Atanasio I hoy están totalmente superados. Es muy posible que su autor sea desconocido, entre 430 y el 500 . Con el paso del tiempo esta composición adquirió suma importancia tanto para Oriente como para Occidente y que durante la Edad Media fue equiparado al Credo apostólico y al Credo niceno y se utilizó en la liturgia.Cf. Denzinger, H. - HünermanN, P., El Magisterio de la Iglesia. Enchiridion Symbolorum. Definitionum et Declarationum de rebús fidei et morum [Dh], Barcelona $2000^{2}$, Dh 75-76. Pp. 80-82.
} 


\section{Artículo VI: De la gracia divina}

Creemos y testificamos que Dios es clemente y no desea la muerte del pecador, sino que el pecador se arrepienta y viva eternamente. Esta clemencia divina es perfectamente libre, sin que exista medio alguno en el hombre o fuera del hombre para influir sobre ella en favor propio. Siendo la Gracia de Dios soberanamente libre, solamente a ella se debe la posibilidad real y efectiva de que el pecador se salve.

\section{Artículo VII: De la Ley de Dios}

Creemos y testificamos que la gracia divina empezó a actuar en favor del hombre inmediatamente después de la caída de éste y que la Ley, dada a conocer al hombre para preservarle de la perdición total, es obra de la Gracia. En la Ley de Dios, sumariamente contenida en los Diez Mandamientos, revela Dios su santa voluntad.

El hombre, por su parte, al verse incapaz de cumplir esta voluntad, reconoce su propia naturaleza pecadora y con ello su miserable situación, de la cual le es imposible salir en virtud de esfuerzos propios, dado que jamás puede cumplir la Ley conforme lo exige la santidad y justicia de Dios.

Asimismo, la Ley de Dios, interpretada y cumplida perfectamente por Jesucristo, sirve de norma de vida al cristiano redimido.

\section{Artículo VIII: Del libre albedrío}

Creemos y testificamos que el hombre es y ha de ser objeto de la Gracia libre y misericordiosa de Dios, pues su naturaleza corrompida le impide obedecer a Dios y confiar en El enteramente. Sin embargo, el hombre, en virtud de ser criatura racional, está en condiciones de cumplir con sus deberes morales y sociales como individuo y como ciudadano, pero no está en condiciones de servir a Dios como Él lo exige y lo espera.

\section{Artículo IX: De Jesucristo, Dios y hombre verdadero}

Creemos y testificamos que Jesucristo es el Verbo de Dios que se hizo carne, adoptando así naturaleza humana y habitando entre los hombres como Jesús de Nazaret. Jesucristo, concebido por el Espíritu Santo en el seno de una virgen, llamada María, es el Hijo Unigénito del Padre y una sola cosa con el Padre y el Espíritu Santo y, por consiguiente, Dios verdadero. En Jesucristo se han unido la naturaleza divina y la naturaleza humana con unidad de persona. En él se ha revelado Dios personal e históricamente al mundo en forma definitiva.

\section{Artículo X: De la obra redentora de Dios en Jesucristo}

Creemos y testificamos que el Padre envió al Hijo al mundo y que el Hijo se humilló voluntariamente para que en él se realizase la Reconciliación. Jesucristo cumplió la voluntad de Dios en perfecta obediencia, humillándose a sí mismo hasta su muerte en la cruz, con lo 
cual libró al hombre de la esclavitud del pecado, ofreciéndole una nueva y verdadera vida de comunión con Dios. Así, Jesucristo se puso en lugar del hombre, llevando su pecado y su culpa y expiándolo en la $\mathrm{cruz}^{63}$.Luego de muerto y sepultado, resucitó el tercer día de entre los muertos, subió a los cielos, y, sentado ahora a la diestra del Padre, intercede por los hombres, al mismo tiempo que permanece entre los suyos por virtud del Espíritu Santo. Por su vida, muerte, resurrección y glorificación se hizo Jesucristo único Redentor y Mediador entre Dios y los hombres, cuya injusticia y desamor se puso de manifiesto crucificando al Unigénito, enviado del Padre.

\section{Artículo XI: De la Elección de la Gracia}

Creemos y testificamos que Dios ha perdonado en Jesucristo todos los pecados, de manera que la Gracia divina elige a los hombres solamente en Cristo, único Mediador y Redentor; y a todo hombre que se acoge arrepentido a la cruz le son perdonados los pecados. Mas la Gracia divina realiza la elección del hombre según la presciencia divina en Jesucristo y nunca fuera de Jesucristo. El hombre que desoye el llamamiento de Dios es responsable de su propia incredulidad, porque Dios no rechaza a ninguno de los que a Él acuden en busca de salvación.

\section{Artículo XII: Del Espíritu Santo}

Creemos y testificamos que el Espíritu Santo es Dios eterno juntamente con el Padre y el Hijo y que sólo por su medio y virtud el hombre puede llegar al verdadero conocimiento de Dios, a la comprensión de su Palabra y a la apropiación de la obra salvadora de Cristo. El Espíritu Santo realiza en los hombres la obra de la regeneración espiritual y de una santificación cada vez más perfecta. Habitando en los creyentes, los protege contra la tentación, los fortalece y consuela, y permanece con ellos eternamente como prenda de su nueva comunión con Dios.

\section{Artículo XIII: Del arrepentimiento}

Creemos y testificamos que todo hombre necesita del arrepentimiento, el cual consiste en que el hombre se reconozca pecador, lo confiese así delante del Dios ${ }^{64}$ tres veces santo y se acoja a su misericordia infinita. Todo hombre que, movido por el Espíritu Santo, haga tal y busque comunión con Dios y se entregue a Cristo con verdadera fe, es el hombre llamado, arrepentido, convertido $y$, también, completamente regenerado o nacido de

\footnotetext{
${ }^{63}$ La Iglesia Evangélica Española, fundada en 1869, es miembro del Consejo Mundial de Iglesias, de la Conferencia de Iglesias Europeas, de la Conferencia de Iglesias Protestantes de los Países Latinos de Europa, de la Comunión Mundial de Iglesias Reformadas y del Consejo Mundial Metodista.

${ }^{64}$ En las Iglesias evangélicas en general no existe ningún reconocimiento del sacramento de la penitencia o de la reconciliación. Aceptan la condición pecadora, pero la confesión no se hace delante de un presbítero, sino solo ante Dios. Probablemente tal condición evolucionó rápidamente como consecuencia de no aceptar ningún tipo de ministerio ordenado, debido a la pérdida en el tiempo de la sucesión apostólica mediante la imposición de manos.
} 
nuevo. Dado que el hombre vive en carne, el Espíritu Santo le llamará no una sola vez, sino de continuo al arrepentimiento, cuyo llamamiento debe atender el nuevo hombre, atribulado de su naturaleza pecadora y deseoso de cumplir la voluntad de Dios por Jesucristo, la cual voluntad es la santificación del hombre creyente. El arrepentimiento es la condición imprescindible para la santificación, que no consiste solamente en el perfeccionamiento moral del hombre, sino en la obra de Dios mismo en el hombre, a la que éste se entrega cada día con mayor sumisión.

\section{Artículo XIV: De la fe}

Creemos y testificamos que por obra del Espíritu Santo nos es otorgado el don de la fe, la cual no consiste tan sólo en tener por cierto lo que señalan las Sagradas Escrituras, sino, sobre todo, en una confianza personal e incondicional en Dios, en la obediencia absoluta a su santa voluntad y en la certidumbre de nuestra eterna salvación.

\section{Artículo XV: De la justificación}

Creemos y testificamos que como el perdón de los pecados alcanza a todos los hombres que se acogen arrepentidos a la cruz de Cristo, cada hombre necesita también ser declarado justo por Dios mismo. Pero esta justificación no la logra el hombre ni por méritos propios ni por ningún esfuerzo personal, sino por la fe en Cristo, Mediador nuestro y Justicia nuestra. Por eso, cuando Dios aplica al hombre creyente la justicia de Cristo, el hombre no sólo es aceptado y perdonado, sino que también vive en Cristo, confía en él, es obediente a Cristo, y es declarado justificado y justo de manera real y cierta.

\section{Artículo XVI: De las buenas obras}

Creemos y testificamos la necesidad de las buenas obras, mas no como méritos que el hombre haga para inclinar a Dios a misericordia, sino como señal patente de la fe y frutos de la misma. Fe sin obras es fe muerta; pues la obediencia en la fe es el cumplimiento de los preceptos divinos. Las buenas obras que Dios ha prometido galardonar son las realizadas por la fe movida por el amor.

\section{Artículo XVII: De la Iglesia}

Creemos y testificamos que Dios nos ha dado el Evangelio para salvación del mundo, y que ha llamado a su Iglesia para dar testimonio, de palabra y obra, de que el Evangelio es la Potencia redentora de Dios. La Iglesia es la comunión de todos aquellos que, elegidos por la Gracia de Dios en Jesucristo, son llamados y congregados mediante el Espíritu Santo, el cual, con la Palabra de Dios, les protege y guarda en la unidad de la fe verdadera hasta el fin del mundo. Por eso es la Iglesia la comunión de los santos, miembros todos ellos del cuerpo de Jesucristo, participantes de las riquezas de su Señor y obligados todos y cada uno de ellos a emplear los dones recibidos en favor de la Iglesia y para edificación de la misma. 
La Iglesia es una, es santa y es universal; y como comunión de todos los creyentes en Cristo, se caracteriza por la predicación pura del Evangelio y la administración recta (o sea, conforme al mandato de Jesucristo) de los Sacramentos.

La unidad de la Iglesia no significa uniformidad o igualdad de ceremonias o formas de culto, ni requiere para su plena realización una sola forma de organización visible ${ }^{65,}$ sino que está fundada y unida en la misma fe en Jesucristo, cabeza de la Iglesia, y en la posesión común del Espíritu Santo.

\section{Artículo XVIII: Del Ministerio en la Iglesia}

Creemos y testificamos que la Iglesia solamente puede realizar su ministerio en obediencia a su Señor y única cabeza, que es Jesucristo, y atendiendo a la dirección del Espíritu Santo. Como el Espíritu Santo es don otorgado a todos los creyentes, éstos son llamados, sin excepción, a ser ministros de Dios en la Iglesia, constituyendo así el "sacerdocio universal" de los creyentes. Por consiguiente, no hay diferencia esencial entre "ministros" y "laicos", y, mucho menos, entre "clero" y "pueblo". No obstante, esto, al Señor de la Iglesia le ha placido desde un principio repartir entre los fieles los diversos dones del Espíritu, creando así el ministerio peculiar de todo creyente, conforme a los dones espirituales que haya recibido.

\section{Artículo XIX: De la Predicación de la Iglesia}

Creemos y testificamos que el ministerio principal de la Iglesia es la predicación del reino de Dios conforme a las Sagradas Escrituras, interpretadas según el Evangelio de Jesucristo crucificado, resucitado y glorificado en los cielos; y, por tanto, también ha de ser predicación de la Iglesia el llamamiento al arrepentimiento y la exhortación a creer en el Evangelio, en espera gozosa de la llegada del reino de Dios en su plenitud.

Sólo a la Iglesia le ha sido encomendada la predicación de la Palabra de Dios que anuncia el Juicio y la Gracia divinos y, en virtud de esta predicación, la Iglesia declara el perdón de los pecados a aquellos que sinceramente arrepentidos aceptan con fe verdadera las promesas de Dios en Cristo. Asimismo, declara la Iglesia la condenación de los incrédulos, amenazados de la ira de Dios, si no se convierten.

\section{Artículo XX: Del Culto de la Iglesia}

Creemos y testificamos que a la Iglesia corresponde la celebración del culto divino. Este culto es tributado sola y exclusivamente al Padre, al Hijo y al Espíritu Santo. Conforme al Evangelio y la costumbre de la Iglesia Apostólica primitiva, integran el culto la lectura y

\footnotetext{
${ }^{65}$ No se acepta la institución del papado, sino que como para las Iglesias ortodoxas, no deja de ser otro obispo más o si se quiere un primus inter pares. No cabe duda que ellos adolecen de una autoridad superior y eso ha provocado en numerosas ocasiones muchos conflictos entre ellos mismos.
} 
predicación de la Palabra de Dios, la Oración, el Cántico y la administración de los Sacramentos.

Habiendo destinado el Creador un día de la semana para que el hombre repose de su obra cotidiana y lo consagre de una manera especial a Dios, este día, que desde la gloriosa resurrección de Cristo es el domingo, debe dedicarse al culto, lo cual no excluye que el culto se celebre también en otros días de la semana.

\section{Artículo XXI: De los Sacramentos}

Creemos y testificamos que Jesucristo, el Señor, ha instituido en su Iglesia dos Sacramentos, a saber: el Bautismo y la Cena del Señor o Santa Cena ${ }^{66}$.

En los Sacramentos no se trata de ritos cualesquiera, sino que los Sacramentos son, juntamente con la Palabra de Dios, los medios de que a Él le place valerse para ofrecernos, otorgarnos y confirmarnos su Gracia en la Iglesia de Jesucristo, y esto no solamente a la comunidad de los creyentes en general, sino también a cada creyente en particular. Jesucristo mismo es el Señor de los Sacramentos y por eso la Iglesia ha de administrarlos fielmente conforme a las palabras de su institución, así como también usando los signos de agua, pan y vino, según el mandato del Señor.

Por eso son los Sacramentos actos sagrados para uso de los creyentes, de manera que todo incrédulo atraerá juicio y condenación sobre sí usando indebidamente de ellos. En los Sacramentos fielmente administrados actúa el Espíritu Santo sobre quienes de ellos participan con fe, aplicándose éstos, por pura gracia, y no en virtud de los signos mismos ni de la piedad o intención del ministrante, todos los beneficios de la Redención consumada por Cristo.

\section{Artículo XXII: Del Bautismo}

Creemos y testificamos que, en virtud del Bautismo, celebrado conforme al mandamiento del Señor, aplicando agua en nombre del Padre, y del Hijo y del Espíritu Santo, al que lo recibe, éste es hecho objeto de los beneficios de la Gracia, incorporado a la Iglesia y hecho partícipe de la redención por la Sangre de Jesucristo, a la cual corresponde como signo el lavado de agua en el Bautismo. Debe recibir este Sacramento toda persona no bautizada, que haya de ingresar como miembro en la Iglesia. Tratándose de persona mayor, ha de manifestar conocimiento de la obra redentora de Cristo, único Salvador, y mostrar sincero arrepentimiento antes de ser bautizada.

Tratándose de niños, cuyos padres, o uno de ellos, o cuyos tutores sean creyentes, también recibirán el Bautismo, porque los beneficios de la Gracia son anteriores a todo conocimiento o voluntad del hombre. Los padres o tutores, así como la Iglesia entera, se

\footnotetext{
${ }^{66}$ Es de todos, conocido que, dentro de la convergencia sacramental, sólo está reconocido a todos los efectos el sacramento de Bautismo. Respecto a la Eucaristía, llamada por ellos Cena, las divergencias son abismales.
} 
hacen responsables de la instrucción de la criatura bautizada, de manera que llegue al conocimiento propio de la salvación en Cristo, su Señor, reconozca la necesidad del arrepentimiento, preste obediencia a la Palabra y tenga siempre en su Bautismo la prenda y señal segura de ser un hijo de Dios. Normalmente, administra el Bautismo el Pastor ordenado por la Iglesia, si bien, en circunstancias especiales, pueda administrarlo otra persona idónea. En modo alguno debe recibir una persona dos veces el Bautismo, pues siendo éste obra de la Gracia divina, no puede perder su significado y eficacia espirituales.

\section{Artículo XXIII: De la Santa Cena}

Creemos y testificamos que, en el Sacramento de la Santa Cena, celebrado conforme al mandamiento del Señor, con ambas especies de pan y vino y pronunciando las palabras de la institución, los creyentes que de él participan gozan de la comunión con la persona de Cristo y su obra redentora. Esta comunión es de carácter espiritual, como espiritual es también la presencia de Cristo resucitado entre los comulgantes, y en virtud de dicha comunión, por obra del Espíritu Santo, se realiza en la Santa Cena también la comunión con el Padre y la comunión entre todos los participantes ${ }^{67}$.En ningún momento de la celebración del Sacramento sufren los elementos pan y vino ninguna alteración ni transformación, sino que siguen siendo pan y vino $y$, no obstante, esto, el creyente se nutre espiritualmente de Cristo y de los beneficios de su muerte. En la Santa Cena, Cristo no es ofrecido ni se ofrece al Padre, lo cual ya sucedió una vez para siempre, ni tampoco se hace en ella Sacrificio alguno para remisión de pecados, sea de vivos o de muertos.

No puede celebrarse el Sacramento de la Santa Cena si no es en memoria del sacrificio único y sin repetición de Cristo en la cruz, más al mismo tiempo dicha celebración es también testimonio de gozosa esperanza en el Señor resucitado, el cual está por venir de nuevo.

La Iglesia tiene autoridad para excluir de la Santa Cena a quienes se resistan a arrepentirse o se manifiesten abiertamente indignos, evitando así caiga sobre ellos el juicio divino. A diferencia del Bautismo, que se administra al creyente una sola vez en su vida, el Sacramento de la Santa Cena puede celebrarse, ora en cada Culto, ora una vez al mes, ora en días determinados, pero siempre en el seno y presencia de la congregación.

\section{Artículo XXIV: De la Confirmación, el Matrimonio y la Ordenación}

Creemos y testificamos que, en virtud de su ministerio la Iglesia puede realizar actos de culto especiales que, si bien no tienen carácter sacramental, ni pueden ser interpretados como mandamientos divinos, resultan provechosos para la edificación de la Iglesia. Entre

\footnotetext{
${ }^{67}$ En la Eucaristía no se da una presencia espiritual de Jesucristo, sino una presencia real, verdadera y sacramental. He aquí las diferencias profundas al respecto.
} 
ellos son los principales: la Confirmación, el Matrimonio y la Ordenación al Ministerio pastoral $^{68}$.

El Bautismo infantil implica que el bautizado, llegado a la mayoría de edad, presente a la Iglesia el testimonio personal de su fe en Jesucristo. Esta ceremonia se denomina Confirmación, por ser la confirmación que el bautizado da de la fe en que fue llevado al Sacramento del Bautismo.

El Matrimonio es institución divina. Su objeto es glorificar a Dios, cumpliendo los cónyuges las leyes naturales propias de este estado, santificándose recíprocamente en la vida conyugal y educando a los hijos en el temor y amor de Dios. La Iglesia al solemnizar el matrimonio exhorta a los esposos al cumplimiento de sus deberes conyugales, sin que este acto ni el matrimonio mismo tengan por ello calidad de Sacramento.

Considerando que en la Iglesia hay hombres llamados y apartados por Dios para el servicio de la misma, la Iglesia les confiere el Ministerio mediante la ceremonia de la Ordenación, amonestándoles y suplicando sobre ellos los dones del Espíritu Santo. La Ordenación no concede al ordenado carácter de persona sagrada, sino que sólo le confiere la autoridad espiritual propia del Ministerio de la Palabra y la administración de los sacramentos.

\section{Artículo XXV: Del Poder Civil}

Creemos y testificamos que toda autoridad civil ha sido instituida por Dios para provecho y paz de los hombres y con el cometido especial de castigar la maldad y proteger a quienes hacen el bien. La Iglesia, como comunión de ciudadanos con derechos y obligaciones para con la autoridad civil, debe prestar a ésta la obediencia correspondiente; pero tanto la Iglesia en su totalidad como cada miembro de ella en particular negará la obediencia a una autoridad que obligue a obrar en contra de la Palabra de Dios, como está grabada en el corazón y la conciencia del creyente, y expresada claramente en las Sagradas Escrituras.

Siempre y cuando la autoridad civil no exija de la Iglesia y sus miembros desobediencia a Dios, consideramos que la Iglesia y sus miembros deben prestarle respeto y apoyo en todo cuanto sea preciso, por eso sin identificarse con ella. La Iglesia, por su parte, debe exigir del Estado plena y garantizada libertad para los creyentes en el Evangelio, así como también para quienes no creen en el Evangelio, y esto no sólo para la multitud de creyentes o incrédulos, sino también para cada individuo que se halle bajo la autoridad del Estado. Asimismo, es obligación de la Iglesia orar y suplicar a Dios por la autoridad civil, sea cual fuere su actitud frente a la Iglesia.

\footnotetext{
${ }^{68}$ Para ellos no son sacramentos ninguno de los tres: confirmación, matrimonio y ordenación Son una especie de ritos. Para la Iglesia católica forman parte de los siete sacramentos.
} 


\section{Artículo XXVI: De la esperanza cristiana}

Creemos y testificamos la vida eterna y la manifestación gloriosa del Reino Eterno de Dios. El hombre que en vida recibió la justificación por la fe, vive en su Señor Jesucristo, y esta comunión no puede ser rota ni siquiera por la muerte. Las Sagradas Escrituras no nos autorizan a afirmar la existencia de lugar alguno de purificación de las almas de los fieles, o Purgatorio. El establecimiento del Reino Eterno de Dios en gloria va unido al retorno glorioso de Cristo, a la resurrección de los muertos, al Juicio Final y a la Creación de nuevos cielos y una nueva tierra.

En el Juicio Final, Dios juzgará a todos los hombres con justicia por su Hijo Jesucristo, para que cada cual reciba lo que corresponda a las obras que en vida hiciera, obras que sean frutos de la fe u obras de la incredulidad. Los que encontraron en esta vida su salvación en Cristo, hallarán confirmada su redención y recibirán la vida eterna en plenitud, gozando eternamente de la presencia de Dios en la Gloria, mientras que los condenados serán excluidos de la participación en estos bienes.

Del retorno de Cristo, así como, por consiguiente, de la resurrección de los muertos, el Juicio Final y el establecimiento glorioso del Reino de Dios, nadie sabe el día ni la hora, sino solamente el Padre Celestial; mas sabemos que el Señor vendrá sin advertencia y a la hora menos esperad ${ }^{69}$. Esta es la confesión o credo de la Iglesia Evangélica español ${ }^{70}$.

\section{DIFERENCIAS ENTRE LA IGLESIA CATÓLICA Y LAS IGLESIAS DE LA REFORMA EN TEOLOGÍA}

Las diferencias básicas que hay entre anglicanos y la Iglesia católica romana son:

- En primer lugar: el dogma de la infalibilidad del papa: éste fue promulgado en el Concilio Vaticano I en el 1879. El anglicanismo no considera que tenga base en las Sagradas Escrituras ni en la tradición de la Iglesia en los Concilios de la misma en los primeros siglos del cristianismo.

- En segundo lugar: la doctrina de la transubstanciación: es la doctrina del cambio físico de pan y el vino en la Santa Eucaristía al cuerpo y sangre de Cristo. La Iglesia Anglicana enseña la Doctrina de la Real Presencia de Cristo en los elementos del Pan y Vino consagrados, pero sin un cambio en la materia ni sustancia de los mismos.

- En tercer lugar: los dogmas de la Inmaculada Concepción y la Asunción de la Virgen María. Para el anglicanismo, estos dogmas no tienen ninguna base bíblica ni tampoco en la tradición de la Iglesia de los primeros Concilios. Puede creerse como devoción privada, pero no se creen necesarios para la salvación.

\footnotetext{
${ }^{69} \mathrm{Cf}$. http://www.iee-es.org/confesion-de-fe/ Consultado el 30-01-2016.

${ }^{70}$ Cf. J. M. MARTínEZ, La España evangélica ayer y hoy. Esbozo de una historia para una reflexión, Barcelona 1994.
} 
- En cuarto lugar: el celibato obligatorio: durante el tiempo de la Reforma en el siglo $\mathrm{XVI}$, la Iglesia de Inglaterra abolió el celibato obligatorio para su clero y deja esta vocación de vida a la decisión de cada cual, es decir, el sacerdote puede elegir si es célibe o casado.

- En quinto lugar: la ordenación de mujeres al presbiterado y al episcopado: Esto es materia de práctica y disciplina de la Iglesia, no de doctrina, al reconocer la completa participación en el Cuerpo de Cristo de todos los hijos e hijas de Dios, incluyendo el llamado a la ordenación.

- En sexto lugar: la forma de gobierno de la Iglesia: En la Iglesia Episcopal el clero, laicado y obispos tienen amplia participación en el gobierno total de la misma. Se celebran Asambleas de feligreses para elegir a sus líderes, mediante la Asamblea diocesana, con representación de todos y de igual forma a nivel internacional ${ }^{71}$.

\section{6. ¿CUÁLES SON LAS DIFERENCIAS ENTRE LAS IGLESIAS DE LA COMUNIÓN ANGLICANA Y LA IGLESIA CATÓLICA ROMANA, RESPECTO A LA DISCIPLINA LITÚRGICA?}

La falta de unidad y de un sistema teológico uniforme en el Anglicanismo ha puesto de relieve, hasta nuestros días, el problema de la ordenación de las mujeres ${ }^{72}$. No es simplemente un problema disciplinar, ni jurídico. La opción adoptada por la mayoría de los obispos anglicanos ha provocado una división y una ruptura en el seno del mismo anglicanismo.

Marca tal distanciamiento radical de la doctrina y de la práctica mantenida tradicionalmente por otras Iglesias cristianas. Esto demuestra la falta de un pensamiento teológico uniforme con relación a un problema que se encuentra al límite de la creencia desde la fe. Muchas han sido las dificultades que han propiciado estas disensiones en las relaciones entre la Comunión anglicana y la Iglesia católica. De aquí que las posturas de la Comunión anglicana pase por estas consideraciones:

\section{Sobre la Sagrada Escritura:}

Frente a la afirmación del Concilio de Trento, la Iglesia de Inglaterra ha afirmado la suficiencia de la sola Escritura para la salvación. De ahí que la Sagrada Escritura no necesita ninguna interpretación exterior. Se interpreta por sí misma, la interpreta la Iglesia y quien la lee. Esta postura no se acepta hoy totalmente por su visión luterana. No acepta hoy dicha interpretación personal pero tampoco acepta la postura católica, que mantiene sobre la Tradición, porque aducen que no es necesaria para interpretar la Palabra de Dios.

\footnotetext{
${ }^{71}$ Cf. J. ESTRUCH, El Protestantismo español, Barcelona 1968.

${ }^{72}$ Cf. D. RuIz DE Miguel, “Ordenación de las mujeres en la Iglesia evangélica”, en VARIOS, Y...Dios creó a la mujer. XII Congreso de Teología (9-13 de septiembre 1992), Madrid 1993.
} 


\section{Sobre Jesucristo, Hijo de Dios y Redentor:}

La teología sobre la Trinidad, de Jesucristo como Hijo de Dios y Redentor y mantenida al largo de cinco siglos es muy parecida a la postura de la Iglesia católica. Se afirman los datos fundamentales de la Cristología, Jesucristo, Hijo de Dios, Dios y hombre verdadero, que no actuó en dos situaciones alternativas, ahora como Dios, ahora como hombre, sino en la unidad personal, la unidad de la persona en todas sus acciones. Hoy no todos comparten estas afirmaciones como el nacimiento virginal de Jesús, la resurrección.

\section{Sobre la Virgen María:}

El anglicanismo ha mantenido un relevante silencio sobre María Virgen. El anglicanismo no ha cultivado la teología mariana. Lo que sí es cierto, es que desde El libro de la Oración común, libro oficial de la liturgia anglicana aparecen las cinco fiestas: Purificación de Nuestra Señora; Maternidad divina o Anunciación; la Visitación; la Natividad de María y la Concepción de Nuestra Señora. Como señal, el nuevo calendario incluyó a san José, esposo de la bienaventurada Virgen. No aceptan los dogmas marianos de la Inmaculada Concepción y la Asunción gloriosa a los cielos, pero los celebran.

\section{Sobre la Iglesia:}

Es la comunidad redimida por la aplicación de la gracia salvadora de Cristo. Comunidad reconciliada con Dios en virtud de la redención de Cristo, que responde al propósito de Dios sobre la humanidad. Aparece la Iglesia como testimonio de la revelación divina; la Iglesia y el ministerio: no acepta la autoridad papal y no hay sucesión apostólica luego no hay ministerio como tal. El ministerio posee una naturaleza espiritual, pero nada más. Hoy hay fuerte división sobre la aceptación de una autoridad superior como el papado.

\section{Sobre los sacramentos:}

La teología sacramentaria es similar a la católica, excepto sobre su número y sobre la intención en la confesión y administración del sacramento. Los dos grandes sacramentos son el Bautismo y la Eucaristía. Sobre el bautismo no hay dificultad, pero sí respecto a la Eucaristía. No aceptan el carácter sacrificial y el sacerdocio en la misma. En cuanto a los otros cinco no tienen valor sacramental, sino que son ritos, dado que no fueron instituidos por Cristo ni tienen fundamento en la Sagrada Escritura ${ }^{73}$.

Si existía falta de uniformidad entre todas las Iglesias que conforman la Comunión anglicana, en cuanto a la liturgia ${ }^{74}$, todavía es mucho más abierto el abanico de posibilidades

\footnotetext{
${ }^{73}$ Cf. E. Llamas MartíneZ, El Anglicanismo. Origen-historia-mensaje, Salamanca 2003, pp. 259-298.

${ }^{74}$ Cf.R. BARón, "La vida litúrgica de los anglicanos”, en Diálogo Ecuménico 4 (1969) 315-322.
} 
que se abre ante las Iglesias luteranas, protestantes y evangélicas, más allá de las sucesivas divisiones que se han producido dentro de su seno ${ }^{75}$.

Los cultos, litúrgicamente variados, a menudo concluyen con un diálogo entre la persona que oficia y la comunidad o congregación. Con posterioridad a la predicación se invita a los asistentes a que pregunten al Pastor. Algo que es inédito a los ojos de la Iglesia católica. Podemos establecer las siguientes cuestiones que siguen siendo afines a todas ellas:

- En primer lugar, no aceptan los siete sacramentos. El Bautismo es el único sacramento aceptado por todas las Iglesias protestantes. Algunas Iglesias aceptan dos sacramentos como tales: Bautismo, Cena del Señor con fuertes variaciones en cuanto a su significado y vinculación con la misma Iglesia

- En segundo lugar, rechazan los siete libros de la Sagrada Escritura: Dejan fuera Tobías, Judith, Sabiduría, Eclesiástico, 1 y 2 de los Macabeos y Baruc. Esto se debe que en principio Lutero aceptó el canon judío de Palestina, 39 libros escritos en hebreo. En realidad, los 46 libros de la Traducción de los Setenta, traducción al griego fue aceptado por los judíos de la Diáspora, por ser el idioma internacional de la época.

- En tercer lugar, no aceptan el culto a las imágenes fundamentados en Éxodo 20, 4: No te harás imágenes ni te postrarás ante ellas. Concluyen que es pecado, pero lo que la Biblia expresa es que está prohibido adorarlas, pero sí venerarlas que es muy distinto.

- En cuarto lugar, no aceptan la devoción mariana. Dicen que los católicos la adoramos como diosa, mientras que la Iglesia católica la venera como madre de Jesucristo, la amamos como Madre y sólo adoramos a Dios.

- En quinto lugar, aceptan que sólo la fe es necesaria para poder salvarse y niegan la necesidad de las buenas obras. No aceptan la postura de la Carta de Santiago 2,17: La fe sin las obras está muerta.

- En sexto lugar, niegan la presencia de Jesucristo en la Eucaristía a pesar que Lutero, su fundador, decía que las palabras de Jesús: Esto es mi cuerpo, son tan expresivas que negar su presencia sólo puede deberse a un ignorante o a un loco ${ }^{76}$.

- En séptimo lugar, no aceptan el sacramento de la reconciliación: los pecados no se perdonan ante un sacerdote sino ante Dios, dejando de lado lo dicho Jesús a sus discípulos: a todo el que le perdonéis los pecados, le quedan perdonados.

\footnotetext{
${ }^{75}$ Cf. J. LORTZ, Historia de la Reforma, Madrid 1964; P. ColuInSON, La Reforma, Madrid2004.

${ }^{76}$ Cf. R. SALADRIGAS, Las Confesiones no católicas en España, Barcelona 1971.
} 
- En octavo lugar, consideran la interpretación libre de la Sagrada Escritura. Cada uno puede interpretar libremente el texto sagrado. Para la Iglesia católica dicha interpretación queda establecida por la propia Iglesia. Con la mera creencia en Dios, el cristiano accede directamente al cielo. No hay purgatorio.

- En noveno lugar, rechazan el culto a los santos. Si lo hacemos, estamos negando que Jesucristo sea el único mediador. La Iglesia católica considera a Jesucristo único mediador, y María y todos los santos, son mediadores ante el único mediador e interceden ante la Santísima Trinidad: Padre, Hijo y Espíritu Santo.

- En décimo lugar, no aceptan la autoridad del papa. No aceptan el ministerio ordenado en sus tres grados: episcopado, presbiterado y diaconado. Tampoco el valor de la Eucaristía como sacrificio incruento en el altar de único y verdadero sacrificio de Jesucristo en la $\mathrm{Cruz}^{77}$.

El bautismo único que posee reconocimiento por parte de las demás Iglesias.

\section{1. Fiestas religiosas de la Reforma}

El año litúrgico luterano está estructurado alrededor de dos festividades claves: Navidad y Pascua, o nacimiento y resurrección. La Navidad es siempre el 25 de diciembre. Pascua es el primer domingo después de la luna llena posterior al equinoccio de marzo. Todas las demás festividades se sitúan por delante o detrás de estas fiestas. El año litúrgico comienza con el Adviento, que son cuatro domingos antes de Navidad. Cada domingo después de éste hasta Navidad es un domingo de Adviento. El 6 de enero es la Epifanía, fija porque la Navidad es fija. El Domingo de Ramos es el domingo anterior al domingo de Pascua, y el Viernes Santo es el viernes antes de Pascua. La fiesta de Pentecostés se celebra siete semanas después de Pascua y marca el fin de la temporada de Pascua ${ }^{78}$. De aquí que todo el calendario litúrgico en las Iglesias cristianas gire alrededor de la Fiesta de Pascua. La solemne Vigilia pascual es la madre de todas las vigilias ${ }^{79}$.

\subsection{Festividades de las Iglesias de la Reforma}

\section{Día de Acción de gracias:}

El evangélico también cree en la Eucaristía o Acción de Gracias, día 22 de noviembre si bien la mayoría de las denominaciones la denominan Santa Cena o Cena del Señor ${ }^{80}$. Es

\footnotetext{
${ }^{77}$ Cf. O. SAlguero, Las comunidades no-católicas de España, Barcelona 1970.

78 Cf. http://www.ehowenespanol.com/luteranismos-costumbres-tradiciones-festividades-religiosas/ Consultado el 30-01-2016.

${ }^{79}$ Cf. San Agustín, Sermón 219: PL

80 Cf. C. Bergendorff, La Iglesia de la Reforma luterana, Londres 1967; Concilio VAticano II, "Decreto Unitatis redintegratio", BAC 526, Madrid 1993; PONTIFICIO CONSEJO PARA LA PROMOCIÓN DE LA UNIDAD DE LOS CRISTIANOS,
} 
más bien un memorial del sacrificio de Jesucristo y señal de la Nueva Alianza del Señor con su pueblo.

\section{Día de la Reforma:}

Es una festividad religiosa celebrada el 31 de octubre en recuerdo de la Reforma protestante. Hoy día la mayoría de las Iglesias protestantes trasladan la fiesta para que pueda caer en domingo o también conocido como Domingo de Reforma, trasladando en ocasiones el Día de Todos los Santos a otro día distinto del 1 de noviembre.

\section{Navidad y la Semana Santa:}

La Navidad es una de las fiestas más importantes del cristianismo, que celebra el nacimiento de Jesucristo en Belén. Esta fiesta se celebra el 25 de diciembre por la Iglesia católica, la Iglesia anglicana, algunas otras Iglesias protestantes y la Iglesia ortodoxa rumana. Son muy similares a las de la Iglesia católica. Poseen los mismos ciclos litúrgicos como el Adviento, Navidad, Epifanía, Cuaresma, Pascua, Pentecostés ${ }^{81}$.

\section{Circuncisión:}

Señor, dígnate aceptar estas alabanzas y acciones de gracias, como espiritual sacrificio que te ofrecemos por medio de Jesús; y perdónanos todos los defectos que en este servicio hayamos cometido por causa de nuestras muchas fragilidades. Circuncida nuestros corazones, para que te amemos con todo el corazón y con toda el alma. Y puesto que en tu providencia nos has dejado ver el principio de un nuevo año, dígnate guiarnos con tu divino Espíritu, a fin de que empleemos en tu santo servicio todos los días que nos resten de vida en este mundo ${ }^{82}$.

\section{Epifanía:}

Te glorificamos, oh Dios, porque tu Hijo eterno asumió, no la naturaleza de los ángeles, sino nuestra naturaleza humana, para ser en todas las cosas semejante a sus hermanos; porque como Hijo del hombre vino para buscar y salvar lo que se había perdido, y como Hijo de Dios se manifestó para destruir las obras del maligno; porque vino con

\footnotetext{
COMISIÓN EPISCOPAL DE RELACIONES INTERCONFESIONALES, Directorio para la aplicación de los principios y normas sobre el Ecumenismo, Madrid 1993; A. ABAD, "La unidad desde la perspectiva de la Iglesia Evangélica Española", en Crítica 57(2007)71-74;M. MARTínez CAVERO, La comunicación entre las Iglesias cristianas, Madrid 1970;J. ESTRUCH, Los protestantes españoles, Barcelona 1967;B. GonZÁlez RAPOSO, "Los matrimonios mixtos. Estado de la cuestión", en Crítica 57(2007)47-51;W. KASPER, “Acerca de la Iglesia”, en Criterio 74(2001)274-280;H. DE LUBAC, Meditación sobre la Iglesia, Bilbao 1961 y Madrid 1980;D. VIDAL REGALIZA, Nosotros los protestantes españoles, Madrid 1968;A. YETANo LAGUNA, Las Iglesias cristianas en la Europa de los siglos XIX y XX, Vol. I, Madrid 1993.

${ }^{81}$ Cf. http://trabajocristianoortodoxoyprotestante.com.es/las-festividades.html Consultado el 30-01-2016.

82 Cf. http://justus.anglican.org/resources/bcp/Spain/Special_Days.htm\#Circumcision Consultado el 30-012016.
} 
potestad, para dar vida eterna a los que creen en él; y porque se dignó revelarse a los Gentiles, a fin de que hallasen salud y gozo en el Deseado de todas las gentes ${ }^{83}$.

\section{Pascua:}

¡Oh nuestro Dios y Padre! Cuán admirable es tu benevolencia y cuán grande el amor que has manifestado hacia los hombres, no por obras de justicia que hubiésemos hecho nosotros, sino sólo por tu infinita misericordia. Te damos gracias, oh Dios, porque Jesucristo nuestro Señor murió por nuestros pecados y resucitó para nuestra justificación; y porque fue declarado Hijo de Dios con potencia, por la resurrección de los muertos. Te bendecimos, porque Jesús, aunque fue muerto, sin embargo, vive, y vive para siempre, y tiene las llaves del infierno y de la muerte; y ni muere ya más ni la muerte tiene dominio sobre él. Te alabamos, porque no dejaste que tu Santo viese corrupción, más soltaste los dolores de la muerte; y así mostraste a la casa de Israel, que al mismo Jesús a quien crucificaron, tú le has hecho Señor y Cristo. Te glorificamos, porque Cristo para este fin murió, y resucitó, y vuelve a vivir, para ser Señor así de los muertos como de los que viven; y para que, o que velemos o que durmamos, vivamos juntamente con él. Ahora, Señor, dígnate aceptar estas alabanzas y acciones de gracias, como espiritual sacrificio que te ofrecemos por medio de Jesús; y perdónanos todos los defectos que en este servicio hayamos cometido por causa de nuestras muchas fragilidades. iOh Señor, Roca nuestra y Redentor nuestro! Que las palabras de nuestra boca y las meditaciones de nuestro corazón sean gratas delante de ti: concédenos lo que te pedimos, y llénanos de esperanza, gozo y paz, por amor de Jesucristo, nuestro bendito Salvador, que contigo y el Espíritu Santo vive y reina por los siglos de los $\operatorname{siglos}^{84}$.

\section{Ascensión:}

¡Oh nuestro Dios y Padre! Cuán admirable es tu benevolencia y cuán grande el amor que has manifestado hacia los hombres, no por obras de justicia que hubiésemos hecho nosotros, sino sólo por tu infinita misericordia. Te damos gracias, porque Jesucristo nuestro Señor subió a su Padre y a nuestro Padre, a su Dios y a nuestro Dios; y habiendo llevado cautiva la cautividad, dio dones a los hombres, para la obra del ministerio, para la perfección de los santos. Te bendecimos, porque como precursor entró en el cielo por nosotros, para prepararnos morada, a fin de que donde Él está podamos también nosotros estar con Él; y se halla sentado a la diestra del trono de tu majestad, estando a Él sujetos los ángeles, y las potestades y virtudes. Te loamos, porque tenemos un Gran Sacerdote tomado de entre los hombres, y constituido a favor de los hombres en lo que a Dios toca, para que ofrezca presentes y sacrificios por los pecados; que puede compadecerse de los ignorantes y extraviados, y que es el autor de eterna salud para todos los que le obedecen. Te alabamos, porque le ensalzaste a lo sumo, y le diste un nombre que es sobre todo nombre; para que en el nombre de Jesús se doble toda rodilla, y toda lengua confiese que Él es el Señor, a la gloria

\footnotetext{
${ }^{83} \mathrm{Cf}$. http://justus.anglican.org/resources/bcp/Spain/Special Days.htm\#Epiphany Consultado el 30-01-2016.

${ }^{84} \mathrm{Cf}$. http://justus.anglican.org/resources/bcp/Spain/Special Days2.htm\#easter Consultado el 30-01-2016.
} 
de Dios Padre: y porque toda potestad es dada, en los cielos y en la tierra, al que es Rey de reyes y Señor de señores, y reinará para siempre, hasta que ponga sus enemigos por estrado de sus pies. Te glorificamos, porque el mismo Jesús que subió a los cielos, se manifestará con sus ángeles, para ser glorificado en sus santos; y congregará de los cuatro vientos a los elegidos, y entonces los justos resplandecerán como el sol en el reino de su Padre. Haz, oh Dios, que, según tu promesa, esperemos cielos nuevos y tierra nueva, en los cuales mora la justicia; y concédenos que, viviendo en esperanza de estas cosas, procuremos con diligencia ser hallados de Él sin mácula y sin reprensión, en paz. Y luego, ven, Señor Jesús, ven pronto. Ahora, Señor, dígnate aceptar estas alabanzas y acciones de gracias, como espiritual sacrificio que te ofrecemos por medio de Jesús; y perdónanos todos los defectos que en este servicio hayamos cometido por causa de nuestras muchas fragilidades. iOh Señor, Roca nuestra y Redentor nuestro! Que las palabras de nuestra boca y las meditaciones de nuestro corazón sean gratas delante de ti: concédenos lo que te pedimos, y llénanos de esperanza, gozo y paz, por amor de Jesucristo, nuestro bendito Salvador, que contigo y el Espíritu Santo vive y reina por los siglos de los siglos ${ }^{85}$. Quizá aquí esta expresado con toda nitidez su pensamiento más profundo.

\section{Pentecostés:}

¡Oh nuestro Dios y Padre! Cuán admirable es tu benevolencia y cuán grande el amor que has mostrado hacia los hombres, no por obras de justicia que nosotros hubiésemos hecho, sino sólo por tu infinita misericordia. Te damos gracias, oh Señor, porque al subir Jesucristo a los cielos, nos envió otro Consolador, que morase con nosotros para siempre: el Espíritu de Verdad, el cual toma de las cosas de Jesús y nos las hace saber. Te bendecimos, porque Jesús, levantado por la diestra de Dios y recibiendo del Padre la promesa del Espíritu Santo, lo derramó sobre sus discípulos como ríos de agua viva. Te loamos por las señales, y milagros, y repartimientos del Espíritu Santo, con los cuales confirmaste la Palabra proclamada por tus siervos. Te alabamos por tu promesa de que, como los padres terrenales, aun siendo malos, saben dar buenas dádivas a sus hijos, así Tú, oh Padre celestial, darás el Espíritu Santo a cuantos lo pidan de ti. Te glorificamos porque, por la virtud del Espíritu Santo, el mensaje de salud es dado a conocer a todas las naciones para obediencia de la fe; y has suscitado a muchos, para dar testimonio ante las potestades de la tierra, con fortaleza y sabiduría irresistibles, y aun en los últimos tiempos reformas y purificas tu Iglesia de los errores y tradiciones que invalidan tu mandamiento. Ahora, Señor, dígnate aceptar estas alabanzas y acciones de gracias, como espiritual sacrificio que te ofrecemos por medio de Jesús; y perdónanos todos los defectos que en este servicio hayamos cometido por causa de nuestras muchas fragilidades. iOh Señor, Roca nuestra y Redentor nuestro! Que las palabras de nuestra boca y las meditaciones de nuestro corazón sean gratas delante de ti: concédenos lo que te pedimos, y llénanos de esperanza, gozo y paz, por amor de Jesucristo,

\footnotetext{
${ }^{85}$ Cf. http://justus.anglican.org/resources/bcp/Spain/Special Days2.htm\#ascension Consultado el 30-01-2016.
} 
nuestro bendito Salvador, que contigo y el Espíritu Santo vive y reina por los siglos de los siglos ${ }^{86}$.

\section{Santísima Trinidad:}

Bendita y sacrosanta Trinidad, Padre, Hijo y Espíritu Santo, nombre sublime e inefable, en el cual fuimos bautizados, y en el cual nos congregamos para el culto religioso, en comunión con la Iglesia Universal. Nosotros te adoramos, te bendecimos, te glorificamos con nuestros cuerpos, nuestras almas y nuestros espíritus. Te adoramos, oh Padre, Señor de cielos y tierra; y a ti, Verbo eterno, que al principio eras con Dios, y eras Dios, sin quien nada de lo que es hecho, fue hecho; que en la plenitud de los tiempos fuiste hecho carne, y habitaste entre nosotros, y manifestaste tu gloria, gloria como del Unigénito del Padre, lleno de gracia y de verdad.

Y puesto que es la voluntad de Dios, que todos los hombres honren al Hijo, como honran al Padre; nosotros te adoramos como el resplandor de la gloria del Padre y la imagen expresa de la Divinidad, uniéndonos así con los ángeles, a quienes fue ordenado que te adorasen. Te rendimos nuestro homenaje, oh Redentor, testigo fiel, primogénito de los muertos, Príncipe de los reyes de la tierra, confesando que tú eres el Cristo, el Señor, a la gloria de Dios Padre. Te adoramos a ti, oh Santo Espíritu, Consolador, a quien el Hijo ha enviado del Padre; Espíritu de Verdad, por cuya inspiración los santos varones de la antigüedad escribieron la Palabra para nuestra enseñanza; y que aun ahora nos enseñas todas las cosas, tomándolas de Jesús y haciéndonoslas manifiestas, para nuestro grande y perennal consuelo. A ti, que eres el Santificador, el Dador de Luz, el Consolador, sea la alabanza para siempre. Ahora, oh Santísimo, Dios uno y trino, dígnate aceptar estas alabanzas y acciones de gracias, como espiritual sacrificio que te ofrecemos, por medio de Jesús; y perdónanos todos los defectos que en este servicio hayamos cometido por causa de nuestras muchas fragilidades. Y a ti, oh Trinidad en Unidad, Padre, Hijo y Espíritu Santo, sea todo el honor y la gloria, por siempre jamás ${ }^{87}$.

De todas las fiestas se puede concluir que mantienen muchas de las que celebra la Iglesia católica. La división ha sido algo determinante ${ }^{88}$.Son fiestas recogidas por la tradición cristiana que incorporaron con toda naturalidad.

\section{LAS IGLESIAS SURGIDAS DE LA REFORMA PROTESTANTE}

Entre todas las divisiones llevadas a cabo después de Lutero están las siguientes:

\footnotetext{
${ }^{86}$ Cf. http://justus.anglican.org/resources/bcp/Spain/Special Days2.htm\#pentecost Consultado el 30-01-2016.

${ }^{87}$ Cf. http://justus.anglican.org/resources/bcp/Spain/Special_Days2.htm\#trinity Consultado el 30-01-2016.

${ }^{88}$ Cf. J. M. GARCía PÉREZ, Los orígenes históricos del cristianismo, Madrid 2007.
} 


\section{Protestantes:}

El papa Julio II se propuso la construcción de una grandiosa basílica y para sufragar los gastos mandó predicar una indulgencia plenaria para todos los que contribuyeran con sus limosnas. En Alemania se asignó la promulgación de la bula al arzobispo Alberto de Brandeburgo, quien encargó al dominico Juan Tetzel la predicación de la indulgencia en Sajonia. Sus predicaciones provocaron las iras de Lutero. El 31 de octubre de 1517 Lutero recurre a la autoridad eclesiástica; este recurso, no atendido, fue el que dio origen a la reforma luterana ${ }^{89}$.Lutero tenía una gran raigambre católica ${ }^{90}$. A pesar de ello fue hereje: opone un individualismo subjetivista contra la autoridad objetiva del Magisterio; opone la Iglesia de la fe a la Iglesia del orden jurídico; niega la eficacia santificadora de los sacramentos, a excepción de la Cena y el Bautismo, interpretados también de un modo subjetivo; la justificación se obtiene por la sola fe; contra la concepción tradicional de la fe como asentimiento y sumisión a la verdad objetiva, afirma que la fe consiste en el encuentro subjetivo con Dios por la confianza.

El término protestante ${ }^{91}$ se remonta a la protestatio que los príncipes y las ciudades luteranas de Alemania presentaron en 1529 contra la decisión de Carlos V de proclamar el catolicismo romano como religión oficial del Estado o Edicto de Worms. Con el tiempo el término se aplicó a todas las iglesias creadas tras la Reforma de Lutero. En la actualidad, el protestantismo es una corriente religiosa muy fragmentada. Su denominador común es la sola Biblia y el hombre con la naturaleza corrupta. Son unos 500 millones aproximadamente.

\section{Luteranos:}

Los más directos seguidores de Lutero. La Federación Luterana Mundial, creada en 1947, agrupa a 147 iglesias de distinto tipo, entre ellas las escandinavas, iglesias de Estado hasta fecha muy reciente. Son unos 60 millones aproximadamente.

\section{Calvinistas o reformados o presbiterianos:}

Conjunto de iglesias inspiradas en la reforma de Juan Calvino (1509-1564). Movimiento protestante más severo que el luteranismo, ya que no admite el libre examen de la Biblia. Tienen una organización fundada sobre los presbíteros, llamados pastores, y sobre los ancianos laicos. Una de sus primeras iglesias fue la de Escocia (1572). Perseguidos en Inglaterra, lograron difundirse con la expansión colonial anglosajona, especialmente en Estados Unidos, Cana, y Australia. Bajo su influjo nacieron los cuáqueros, secta que rechaza todo dogma y sacramento. La más importante rama son los baptistas. Son unos 50 millones aproximadamente.

Anglicanos:

\footnotetext{
${ }^{89} \mathrm{Cf}$. G. URRUTIA, Iglesia y Sociedad. Una aproximación desde el pensamiento protestante, Madrid 2002.

${ }^{90}$ Cf. L. F. MATEO-SECO, Martín Lutero: Sobre la libertad esclava, Madrid 1978.

${ }^{91}$ Cf. J. BAUBÉROT, Historia del protestantismo, México 2008.
} 
Es la Iglesia nacional de Inglaterra, escindida de Roma en 1534 con la aprobación por parte del Parlamento inglés del Acta de Supremacía que reconocía en el rey Enrique VIII al único jefe de la iglesia en Inglaterra. En 1783, sufrieron la escisión de los metodistas. La comunidad anglicana, dividida en tres ramas: High, Low y Broad Church, cuenta con 450 obispos, repartidos en 124 países, que guardan fidelidad al arzobispo de Canterbury, y constituyen la Comunión Anglicana. En Estados Unidos se llama Iglesia Episcopal ${ }^{92}$. Son unos 70 millones aproximadamente.

\section{Metodistas:}

Fundado por los hermanos John y Charles Wesley, constituyó una de las primeras grandes iniciativas de evangelización popular, con grandes mítines dirigidos al proletariado urbano. Gran difusión en Estados Unidos a través de las misiones en el lejano oeste. Se llaman metodistas por su énfasis en la piedad interior, la devoción y la santificación personal. Son unos 50 millones aproximadamente.

\section{Pentecostales:}

Nacen en 1830 de los metodistas en las comunidades negras, y entre los inmigrantes europeos de Estados Unidos. Muy difundidos en los sectores sociales más pobres. Profecías, curaciones, revelación y liberación de los sentimientos. Experiencia personal del Espíritu Santo. Tienen cierta influencia en el surgimiento en la Iglesia católica de los movimientos de renovación carismática. Dan origen en Francia, en 1952, a la Iglesia Evangélica de Filadelfia, propia de la etnia gitana. Probablemente sean los más conocidos, puesto que esta etnia se encuentra repartida, por toda Europa, especialmente. Por eso son muchos los que se encuentran entre sus seguidores. Pueden ser unos 200 millones aproximadamente.

\section{Baptistas:}

Nacida a finales del siglo XVII en Amsterdam, pero concentrada después en Estados Unidos. Basada en el sacramento del Bautismo de los adultos por inmersión, la Biblia como autoridad universal y libertad teológica. Activa en las misiones. Propugnan la separación entre Iglesia y Estado. De los baptistas surgen los adventistas. Hoy no llegan a los 40 millones aproximadamente.

\section{Adventistas:}

A principios del XIX por Villiam Miller, agricultor baptista de Massachusetts, que esperan una segunda y definitiva venida de Cristo a la tierra. Divididos en unos cincuenta grupos, uno de los más activos es el de los adventistas del Séptimo Día. Son unos 5 millones aproximadamente.

\section{Anabaptistas o Menonitas:}

\footnotetext{
${ }^{92}$ Cf. J. B. VILAR, Un siglo de protestantismo en España 1893-1979, Murcia 1979.
} 
Fueron un vasto fenómeno de evangelismo popular que se configuró como el ala izquierda de la Reforma protestante. Duramente criticados por Lutero, sólo administraban el bautismo a los adultos, y predicaban la separación entre la comunidad cristiana y el resto de la comunidad civil, por lo que fueron severamente perseguidos, especialmente en Alemania $^{93}$. Reorganizados por Menno Simons, tomaron el nombre de menonitas y se convirtieron en una Iglesia de fuerte carácter pacifista, especialmente radicada en Estados Unidos. No llegan al millón y medio aproximadamente ${ }^{94}$.

\section{LOS SERVICIOS RELIGIOSOS}

Los servicios religiosos se dividen en: la etapa de reunión, la etapa de la Palabra y la etapa de la Cena y la salida. Muchas iglesias luteranas no ofrecen la cena, o comunión, en cada servicio religioso, sino una o dos veces por mes. La etapa de reunión típicamente consiste en un preludio instrumental, himnos y cánticos y la oración. La Palabra consiste en la lectura del Antiguo Testamento, las Epístolas de san Pablo y el Evangelio; las lecturas están programadas de manera que se pueda cubrir la mayor parte de la Sagrada Escritura en un período de tres años. La comunión usualmente sigue la recepción de regalos, u ofrendas, las oraciones de intercesión y el intercambio de la paz. La salida consiste en cánticos, bendición y la salida usualmente acompañada con un himno ${ }^{95}$.

\section{1. Celebración del matrimonio}

\subsubsection{Celebración en la Iglesia anglicana}

La Comunidad anglicana presentó un documento titulado Men and Women in Marriage u Hombres y mujeres en el matrimonio, de 13 de abril de 2013, en defensa del matrimonio entre hombre y mujer y de la familia tradicional como el mejor contexto para el crecimiento de los niños. El matrimonio es, en el orden de la creación, un don de Dios y un signo de su gracia, y es la unión estable, fiel y de recíproco apoyo entre un hombre y una mujer, sancionada jurídicamente, central para la estabilidad y el bienestar de la sociedad humana ${ }^{96}$. La doctrina protestante y anglicana, que aparece en el siglo XVI, defiende la jurisdicción de la potestad civil sobre el matrimonio por voluntad divina. En estos casos niegan el carácter sacramental del matrimonio, por lo que como consecuencia lógica establecen la necesidad de la Iglesia de abstenerse de regular esta institución

\footnotetext{
${ }^{93}$ Cf. M. García Alonso, La teología política de Calvino, Barcelona 2008, p. 18.

${ }^{94}$ Cf. http://www.teologiamoral.com/ecumenismo/ Consultado el 30-01-2016.

95 Cf. http://www.ehowenespanol.com/luteranismos-costumbres-tradiciones-festividades-religiosas/ Consultado el 30-01-2016.

${ }^{96}$ Cf. CHURCH HOUSE, Common Worship: Services and Prayers for the Church of England. Pastoral services, London 2015, pp. 101-193.
} 
Al hablar de matrimonio celebrado en la forma religiosa anglicana nos planteamos ante todo una especificidad litúrgica y no un derecho matrimonial anglicano propio, al igual que las demás Iglesias surgidas tras la Reforma, lo que se deja de lado es lo estrictamente jurídico para dar mayor trascendencia a lo pastoral. Prueba de ello es el reconocimiento entre fieles anglicanos del matrimonio celebrado en forma civil. Para los anglicanos el matrimonio es considerado una institución natural, una institución sagrada y una institución que participa a la vez de una naturaleza secular, por cuanto su regulación y su disolución corresponden siempre a la legislación civil. La celebración en forma religiosa supone una presentación del rito sacramental ante la misma Iglesia para la recepción de la bendición nupcial. Se admite el divorcio, pese a ser considerado un error y la Comunión anglicana no posee una jurisdicción de aplicación propia que resuelva los litigios matrimoniales, los cuales quedan siempre reservados para su funcionamiento en la jurisdicción civil. Surgió el nombre de luterana a partir de la reforma de la Iglesia en el siglo XVI que hicieron un grupo de teólogos entre los que se encontraba Martín Lutero, de allí que también se conozca por la rama protestante. Hay varias ramificaciones de esta Iglesia que son la evangélica, calvinista, anglicana. También hay ramificaciones menores como son los quáqueros, presbiterianos, etc. Para los protestantes no existe una cabeza como en el caso de los romanos que es el papa, sino que consideran como única cabeza de su Iglesia a Cristo. Los protestantes, a diferencia de otras Iglesias, no consideran al matrimonio como sacramento. Se trata un compromiso con Dios y con toda la comunidad.

En lugar de un presbítero, quien oficia es un pastor. Se realiza con este pastor una entrevista previa a la boda. Se ultiman detalles con él mismo. Éste es quien los va a bendecir en el momento del casamiento. $Y$ el resto es muy similar, donde también está el intercambio de los anillos de ambos, como símbolo de su unión. Más allá de las distintas tradiciones de la Iglesia católica, la similitud de todas es que guardan un gran simbolismo a la hora de realizar un casamiento. Las más conocidas son la Iglesia anglicana de san Jorge y la comunión anglicana Iglesia Española Reformada Episcopal ${ }^{97}$.

\subsubsection{Celebración en la Iglesia evangélica}

El matrimonio es una institución civil, así como religiosa, y por lo tanto sujeto a reglamentos legales. El ministro deberá familiarizarse con las leyes del Estado o nación donde vaya a ejecutarse esta ceremonia, para estar seguro de cumplir con los requisitos de la ley. Además de llevar un registro en el cual hará constar los matrimonios con todos los datos necesarios, la firma de los contrayentes, los testigos y el ministro. La ceremonia se puede verificar en el templo, en una casa particular, pero siempre ante testigos. En muchos países es preciso que los contrayentes presenten el certificado de las autoridades civiles, comprobando que ya se ha verificado el matrimonio civil en su forma legal, dependiendo de las diversas legislaciones al respecto.

\footnotetext{
${ }^{97}$ Cf. http://www.stgeorgesmadrid.org/ Consultado el 16-12-2015 y http://www.anglicanos.org/ Consultado el 16-12-2015.
} 
La celebración del matrimonio es siempre responsabilidad de las Iglesias, los libros de registros y las actas de los matrimonios religiosos, así como el funcionamiento para la obtención de la acreditación y capacitación de sus ministros, sean varones o mujeres, pastores y pastoras y sacerdotes. Aunque los requisitos para poder oficializarse una boda cristiana evangélica son los mismos requeridos que a nivel civil en la mayoría de los países, a este se le debe incrementar las exigencias que mantiene cada Iglesia cristiana evangélica acorde a su doctrina y disciplina ${ }^{98}$.Los requisitos para celebrar la boda evangélica son:

- En primer lugar, ambos contrayentes deben ser miembros de una Iglesia y en el caso de ser de diferentes Iglesias es necesario presentar carta pastoral, de su pastor.

- En segundo lugar, ser miembros de una Iglesia y haber sido bautizados. De no estarlo será preciso pasar por la petición de recibir el Bautismo.

- En tercer lugar, llevar adelante un programa de ayuda prematrimonial que debe realizarse unos seis meses antes de la celebración del matrimonio. Dicha asesoría prematrimonial incluye, pero no se limita, a temas tales como los siguientes: Conocer a la pareja, las razones para casarse y celebrar el matrimonio, el amor entre ambos, la comunicación que debe ser interpersonal, el funcionamiento de la economía familiar y la relación afectiva, psicológica y sexual.

Independientemente de cumplir las exigencias de su Iglesia, también deben recopilar la documentación civil necesaria que le sirve a su pastor o ministro para completar el libro de registro y las actas de matrimonio que deberá llevar el representante de su Iglesia al registro de la oficina correspondiente civil, no más tres días hábiles tras la celebración de la boda o matrimonio.

\subsubsection{Elementos necesarios en el matrimonio evangélico y protestante}

- Es un acto de "responsabilidades".

- No se pide la partida bautismal. Sólo se exige el matrimonio civil.

- La ceremonia en el templo se considera como una bendición.

- Los protestantes pueden casarse con personas de otras confesiones.

- Es necesario reunirse con el pastor varios meses antes del gran día. Habrá que concertar cuatro entrevistas para preparar a los futuros esposos en su matrimonio.

\footnotetext{
${ }^{98}$ Cf. http://www.iee-es.org Consultado el 16-12-2015; Igualmente http://www.friedenskirche.es/ Consultado el 16-12-2015.
} 
- La ceremonia tendrá lugar en el templo, la Iglesia reformista o, muy raramente, en el exterior o en un lugar no religioso... Con la condición de haber obtenido la aprobación del oficiante.

- Los testigos, generalmente uno por cónyuge, firmarán los registros después del intercambio de anillos.

- La ceremonia se funda en la lectura de textos sacados de la Biblia. En consecuencia, dedica a su selección una especial atención.

\subsubsection{Celebración del matrimonio evangélico}

Podemos afirmar que el matrimonio es entendido como un compromiso con Dios y con la comunidad cristiana, los miembros de la Iglesias protestantes no consideran dicha celebración matrimonial como un sacramento. Se puede comprender fácilmente las similitudes que posee la celebración protestante en referencia con la celebración de la Iglesia católica, excepto en la dimensión sacramental que tiene para los católicos. La novia va vestida de blanco. La ceremonia la preside siempre un Pastor protestante o ministro adecuado, según las diversas Iglesias y Comunidades eclesiales. Es el encargado de otorgar la bendición a la acción sacramental. Igual que ocurre en la celebración o rito católico, los novios deben haber realizado un curso prematrimonial o entrevista previa. Debe presentarle el Acta civil del matrimonio y establecer los últimos detalles de la ceremonia religiosa. Existe el intercambio de los anillos, realizada entre los novios que manifiesta la unión y el compromiso entre ambos con marcado carácter simbólico. El ministro debe de estar familiarizado con las leyes del Estado o Nación donde vaya a celebrarse la ceremonia nupcial, para estar seguro de cumplir con los requisitos de las leyes.

Se ha de llevar un registro en el cual hará constar los matrimonios ya celebrados con todos los datos necesarios, además de la firma de los contrayentes, los testigos y el ministro que preside la ceremonia. Ésta puede llevarse a cabo en la iglesia o en una casa particular, pero siempre ante auténticos testigos. En el matrimonio anglicano, el celebrante no sólo es testigo sino también intermediario. Aunque el matrimonio no es un sacramento, sin embargo, por el motivo de que aquellos que se casan deben hacerlo en el Señor. Tienen una necesidad especial de instrucción, dirección y exhortación de la Palabra de Dios cuando entran en esa nueva relación, así como de la bendición de Dios sobre su matrimonio. Por tanto, es apropiado que el matrimonio se haga de manera solemne por un pastor de la Palabra de Dios, para que los pueda aconsejar adecuadamente y les ofrezca la bendición ${ }^{99}$. Se sigue al Señor en el matrimonio dentro de las situaciones históricas y cambiantes ${ }^{100}$.

\footnotetext{
${ }^{99}$ Cf. D. J. AtKInson - D. H. Field - O. O'Donovan - A. Holmes, Diccionario de Ética Cristiana y Teología Pastoral, Barcelona 2004, p. 784.

${ }^{100}$ P. LehmanN, La ética en el contexto cristiano, Montevideo 1968, p. 141.
} 
El matrimonio ha de ser entre un hombre y una sola mujer exclusivamente; no han de tener los grados de consanguinidad o parentesco que prohíbe la Palabra de Dios; las parejas deben tener ya de una edad de discernimiento, capaces para tomar sus propias decisiones, o, con buenas razones, darse su consentimiento mutuo. Previo a la celebración del matrimonio, el propósito del mismo será anunciado por el pastor o ministro con tres semanas de anticipación ante la congregación, en el lugar o lugares respectivos donde tengan su residencia. Tras dicho anuncio, el pastor o ministro los unirá en matrimonio con el testimonio de los testigos, antes que proceda al solemne acto de la celebración del matrimonio. Se ha de comunicar siempre a los padres, para procurar su consentimiento. Los progenitores nunca deben forzar a sus hijos a que contraigan matrimonio sin su libre consentimiento, pero tampoco negarlo sin motivos justos. Desde el anuncio hasta su celebración no debe pasar mucho tiempo. Así pues, el ministro, habiéndolo anunciado con tiempo suficiente, si no se ha presentado ningún impedimento, debe comunicarlo públicamente de manera solemne en el lugar propuesto para su aprobación pública, ante un número de testigos que se tienen como dignos de confianza; a una hora conveniente del día, en cualquier tiempo del año, excepto en días de ayuno. Se aconseja que no se haga en el Día del Señor ${ }^{101}$.

\section{2. Celebración de Exequias. El funeral y ritos mortuorios}

El oficio de sepelio o funeral se reserva para aquellos que en su vida y hasta su muerte han hecho y vivido su existencia como profesión de cristianos. De ahí que, no debe usarse en el entierro de los adultos que mueren sin haber recibido el Bautismo; ni de los que voluntariamente se suicidan; ni de los que han dado en su vida y muerte pruebas inequívocas de que no creían en Cristo. En tales casos, si el ministro, por razón de las circunstancias, hubiere de intervenir en el entierro, podrá realizar cualquier modificación del oficio que no repugne con la verdad de los hechos ${ }^{102}$. Cuando alguna persona fallece y abandona de vida, el cuerpo del difunto, en el día del entierro, será acompañado adecuadamente desde la casa al lugar establecido en el cementerio para proceder a su entierro ${ }^{103}$.La realización del culto mediante el funeral tiene una connotación para toda la Iglesia y que todos sus miembros se pueden hacer presentes en este espacio apropiado. Los miembros de la Iglesia, en función de la proximidad al fallecido, se deben poner en contacto con los familiares, bien desde antes o con posterioridad al suceso, si la muerte ha ocurrido debido a una enfermedad. En el caso que la familia considere que la ceremonia debe realizarse de manera más íntima, sólo los integrantes más cercanos de la congregación acompañarán en los ritos funerarios. El culto fúnebre es una oportunidad para reflexionar y considerar esta bisagra entre la vida mortal y la vida divina. El mensaje general que se

\footnotetext{
${ }^{101}$ Cf. http://www.presbiterianoreformado.org/estandares/ Consultado el 30-01-2016.

102 Cf. http://justus.anglican.org/resources/bcp/Spain/burial.htm Consultado el 30-01-2016.

103 Cf. CHURCH House, Common Worship: Services and Prayers for the Church of England. Pastoral services, London 2015, pp. 255-334.
} 
promociona en el rito apela a la consolación, expectativa de un futuro encuentro con Dios, meditación y sensibilidad ${ }^{104}$.

\section{INDUMENTARIA LITÚRGICA}

Los paramentos son las diversas decoraciones que cuelgan y decoran el altar frente al santuario. Los paramentos luteranos son similares a los católicos en relación a que el color predominante simboliza la temporada litúrgica y su clima. El color del Adviento es azul, el cual simboliza la esperanza de la espera del nacimiento de Cristo. La Navidad y la Epifanía son simbolizadas con el blanco, el color de la paz, por la entrada del Príncipe de la Paz en el mundo. La Cuaresma es representada con el violeta, el cual simboliza la actitud de penitencia a medida que el camino de Cristo lo acerca cada vez más a la crucifixión. El negro simboliza el Viernes Santo, el signo de muerte por la muerte de Jesús en la cruz. El blanco simboliza el júbilo de la Pascua ya que Cristo resucitó. El rojo representa Pentecostés, momento en el que el fuego del Espíritu Santo unge la Iglesia. El verde es para los otros domingos de la iglesia, que simboliza la metáfora de la parra con muchas ramas ${ }^{105}$.

En las Iglesias de la Reforma, a partir del siglo XVI, rechazaron por principio los colores como complemento del culto. Más tarde, especialmente los calvinistas negaron los colores y las texturas de la ropa litúrgica, usando una toga negra que se sobreponía sobre la ropa de calle. Con posterioridad se fueron de nuevo introduciendo los colores para la liturgia, especialmente los luteranos y anglicanos, pero admitiendo otra gama de colores como el caso del color amarillo que puede sustituir al verde. En el tema de la indumentaria litúrgica los más atrevidos y más vanguardistas han sido siempre los anglicanos, pero eso no quiere decir que hayan sido las más aconsejables o prudentes. Hay otras Iglesias que rompen con el rigorismo formal con figuras geométricas y se aventuran con un diseño inspirado en algunos artistas de reconocida fama mundial. El color dorado suele sustituir a los demás colores excepto el morado que posee carácter penitencial. Dicho color ya se ha visto incluso en días señalados para celebraciones especiales en la propia Iglesia católica. El vestuario normal de un ministro anglicano en ceremonias normales consiste en un roquete con una especie de sobrepelliz morado o negro, una holgada indumentaria de lino con amplias mangas.

\section{PRECEDENCIAS Y TRATAMIENTOS}

Las precedencias en las Iglesias protestantes, se hace por orden de antigüedad: anglicanos, evangélicos, luteranos, reformados, calvinistas, etc. No hay que perder de vista en que los países del norte de Europa, cada una de ellas es la religión oficial de cada Estado. Las precedencias se hacen en función de la categoría que se ostenta: arzobispo, obispo,

\footnotetext{
${ }^{104}$ Cf.http://es.scribd.com/doc/115397065/Rito-funebre-segun-Iglesia-Evangelica Consultado el 30-01-2016.

Cf. http://www.ehowenespanol.com/luteranismos-costumbres-tradiciones-festividades-religiosas/ Consultado el 30-01-2016.
} 
pastor y diácono. Finlandia, Suecia, Noruega, Dinamarca e Islandia tienen como religión el luteranismo ${ }^{106}$.

El tratamiento de padre se puede escuchar en la Iglesia luterana de manera continua. Dicho tratamiento proviene de cierto conservadurismo, que en numerosas ocasiones estaba en contraposición del ministerio pastoral. Dicho tratamiento pertenece a una concepción de Iglesia más tradicional que a la dimensión de las nuevas percepciones de la Iglesia luterana más actual. Otro tratamiento es el de pastor, más acorde con las influencias de las Iglesias protestantes y evangélicas. Es un tratamiento mucho más aceptable. El primero, padre, no es oficial. La forma de Reverendo o Muy Reverendo se introdujo especialmente en las Iglesias cristianas de Occidente. Por tanto, el que más se usa y además es el más adecuado, sin duda, es el de pastor ${ }^{107}$.

Se puede añadir el nombre del mismo para las ocasiones más formales. Llamar al pastor por su nombre no entra en la tradición de la Iglesia. En caso de los obispos, su tratamiento es el de Señor obispo; para el caso de los arzobispos, será Su Eminencia; para el caso de predicadores, diáconos y demás servicios serán siempre hermano o hermana; si se dirige a toda la comunidad eclesial será el título de hermanos y hermanas. En la Iglesia anglicana o Comunión anglicana, los arzobispos de Canterbury y de York poseen el título de Su Gracia; los obispos, Ilevan el nombramiento de Lord; los canónigos de Sir; los presbíteros de Reverendo ${ }^{108}$. El funcionamiento entre el pastor y los cristianos laicos, las diferencias son solamente de función, pero no de esencia, pudiendo cualquier persona con la formación adecuada desempeñar el mismo papel. El pastor protestante es siempre nombrado por la Iglesia local y no por una jerarquía, dado que no existe, existiendo Iglesias en las que no existe presbítero o pastor. No obstante, la dirección de la Iglesia es ejercida de un modo más colegial incluso asambleario que jerárquico, si bien algunas Iglesias aceptan alguna forma de episcopado. La autoridad del obispo es también funcional y ejercida entre iguales.

Por último, al no existir una máxima autoridad infalible, como es el caso del papa de Roma en la Iglesia católica, se favorece la pluralidad de doctrinas e interpretaciones. En las Iglesias Reformadas el título es de presidente con tratamiento de señor Presidente. Normalmente los criterios que se pueden fijar al establecer ciertos sistemas de precedencias a la hora de acomodar los representantes de las distintas Iglesias y Confesiones religiosas, se pueden tener en cuenta los aspectos siguientes: la edad, en cuanto posibilita un sistema acertado para no perjudicar a nadie desde el principio. Otro criterio es la dignidad. Todos como hombres son igualmente dignos, pero se acomoda a este otro aspecto cuando se ostenta los diversos cargos o servicios dentro de las comunidades protestantes. Por último, se puede tener en cuenta el gobierno: si se ostentan diversos puestos de gobierno será siempre muy bueno tenerlos en cuenta. Son criterios muy fáciles, claros y aceptados buenamente: edad, dignidad y gobierno.

\footnotetext{
${ }^{106}$ Cf. J. ORLANDIS, Historia breve del Cristianismo, Madrid 1999, pp. 123-124.

${ }^{107}$ Cf. http://protocoloeclsiasticoymilitar.blogspot.com.es/ Consultado el 30-01-2016.

${ }^{108}$ Cf. http://www.eventoygestion.net/2012/08/tratamientos-religiosos.html Consultado el 30-01-2016.
} 


\section{CONCLUSIÓN}

El anglicanismo desde su origen, teniendo en cuenta toda su historia ha intentado ofrecer el mensaje desde su perspectiva, haciendo posible una nueva visión a un mundo tan necesitado de luz, de amor a Dios y a los hombres, con la debida instrucción religiosa y mediante el testimonio de vida. La Comunión anglicana posee un lugar especial entre las confesiones cristianas y ha mantenido una relación singular con la Iglesia católica. Incluso se puede afirmar que desde su mismo origen quiso ser Iglesia católica, universal, apostólica, unida a la Iglesia tradicional y en plena comunión espiritual con ella, aunque separada jurídicamente de la Iglesia de Roma. Hoy sigue manteniendo los mismos dogmas trinitarios y cristológicos definidos por los antiguos concilios, pero no está sometida a la autoridad del Santo Padre, puesto que, para ellos, sólo es obispo de una Iglesia particular. La dificultad siempre se ha visto en la aceptación de alguien superior, que venía representado por la Iglesia romana. Pero todo ello, supone de hecho, una auténtica paradoja y si nos ponemos rigurosos una contradicción en sí misma, por muchos esfuerzos que se hagan para atemperar y suavizar los límites de la separación, o los términos en los que se expresan. Esto ha llevado primordialmente a establecer opuestas interpretaciones e incluso como definido con gran exaltación o vilipendiado hasta la más severa crítica. No es ni lo uno ni lo otro. Siempre han tenido la facilidad de celebrar la liturgia que les había ayudado tradicionalmente a saber penetrar en los misterios de Dios y acceder a la Cena del Señor con una gran flexibilidad, viva, entusiasta e incluso realismo que lo había hecho la liturgia romana. Indudablemente lo mismo ocurría con el sentido de la escucha de la Palabra de Dios con unas fuertes resonancias para aquellos que vivían dicha sensibilidad religiosa. Pero todo ello se fue perdiendo en el correr del tiempo debido a las desviaciones que fueron apareciendo, a los errores no enmendados, por aquellos que debían ser los mejores baluartes $o$ adalides de la propia comunidad eclesial.

Esto llevó inexorablemente a una paulatina separación entre la fe y la praxis, entre la liturgia y la vida, entre lo esencial y lo accidental. Llegaron a influir negativamente la penetración inadecuada del racionalismo, el criticismo y el particular liberalismo que minaron la fe y perjudicaron la fuerza misma de la Iglesia, que fue incapaz de conseguir motivar de nuevo a sus miembros. La pérdida de los valores espirituales, transcendentales y esenciales, pero manteniéndose como una especie de institución benéfica, social, cultural o educativa como hoy pudiera ser una ONG. No se trata de eso, pues ninguna Iglesia o Comunidad eclesial es eso, ni mucho menos. Durante los siglos XVII y XVIII se producen muchas decepciones, con numerosas quejas de los teólogos y las voces persistentes de los fieles que denunciaban los hechos. Llegándose a decir que "la Iglesia anglicana es un club, que consta de un conjunto de reglas, que no ha aceptado" ${ }^{109}$. En muchas ocasiones ha carecido de las fuerzas necesarias para poder iniciar todo un proceso de renovación interna y a la vez estructural para poder despegar, desde el mismo interior del anglicanismo. Tampoco consiguió renovar su imagen ante una sociedad que reclamaba cambios de fondo,

\footnotetext{
${ }^{109}$ Cf. A. D. Toledano, El anglicanismo, Andorra la Vieja, 1959, p. 121.
} 
con sentido, con nueva visión de la realidad religiosa de sus comunidades que pedían esos $\tan$ necesarios cambios ${ }^{110}$. No está del todo claro, pero los movimientos de acercamiento a la Iglesia católica, por parte de muchos de sus miembros, tanto fieles como cierta jerarquía, atormentados porque los cambios de finales del siglo XX, no eran los que ellos necesitaban.

Cuestiones que les apartaban de su fe y de la Iglesia católica. Esto llevaría a que el 4 de noviembre de 2009, el papa Benedicto XVI publicase la Constitución apostólica Anglicanorum coetibus, para todos aquellos que quisieran entrar en la Iglesia católica. En el caso de la Iglesias nacidas de la Reforma luterana del siglo XVI, el abanico de divisiones existentes dentro de ella, hace muy difícil aglutinar todo un pensamiento de carácter unificado, cuando ellas han procedido a la división continua. Esto ha provocado más sufrimientos en los propios feligreses, muchas veces desatendidos o simplemente desorientados ante tantas posturas pero que no llegaban a calar en los fieles. La reforma protestante quiso volver a la Sagrada Escritura, dejando de lado los problemas planteados por la Escolástica. Su fin era conseguir liberar el dogma de toda influencia de tipo filosófico. Aunque podía tener aspectos positivos, no cabe duda que alejar el pensamiento filosófico del campo del pensamiento sistemático corría el peligro de introducirlo de un modo oculto pero determinante dentro de la misma exégesis.

Por otra parte, el principio ya advertido anteriormente de la libre interpretación abría el camino a las más diversas opiniones. Si se perdía la unidad, los lazos de la Tradición se diluían y la Sagrada Escritura se perdía entre las posturas filosófico-científicas del momento histórico. ¿Dónde quedaba la liturgia? ¿Qué interpretación bíblica era la auténtica? ¿Quién asumía los retos de las Iglesias? Los diálogos con la Iglesia católica han conseguido desbloquear la persistente enemistad histórica que han padecido ambas Iglesias. Éstas han discutido y a veces regateado la eclesialidad de ambas Iglesias. Fueron muchas las razones, pero quizá la mejor aclaración con respecto a la dogmática, lo que creen cada una de ellas, ha sido la renuncia reciproca a la teología de la confrontación y la controversia mutua. Este sentido de eclesialidad no es reconocido en paridad por ambas partes, porque no se acepta la evolución dogmática que fue conduciendo a una objetiva realidad histórica que constituye la Iglesia en su estructura sacramental y ministerial.

Las Iglesias reformadas creen ver en la tradición dogmática de la Iglesia católica elementos de difícil extracción de la Sagrada Escritura. Ante esta situación es necesario percibir que, en el contexto tradicional, en la vida de la Iglesia, ha imperado la sola Escritura, y que ella ha gobernado la doctrina de la fidelidad de la reforma a la misma Escritura. No obstante, la fidelidad de las Iglesias reformadas, a la tradición simbólica más antigua, parece contradecir su resistencia a la aceptación plena de la misma vida de la Iglesia en su objetiva verdad histórica como la expresión de la tradición ${ }^{111}$. De todas maneras, queda todavía lejos la alternativa de una convergencia sobre la realidad sacramental de la Iglesia y la estructura

\footnotetext{
${ }^{110}$ Cf. E. Llamas MARTíneZ, El Anglicanismo. Origen-historia-mensaje, Salamanca 2003, pp. 23-26.

${ }^{111}$ Cf. A. GonZÁlez MONTES, "El diálogo teológico católico-reformado", en P. LANGA AGUILAR, (DIR.), Al servicio de la unidad, Madrid 1993, pp. 449-450.
} 
orgánica de la tradición, dado el sentido ministerial de la autoridad en la Iglesia y su alcance magisterial. Es obvio que ese sentido de autoridad y la fuerza sacramental pesa muy fuertemente. Toda la fuerza del ministerio ordenado en su triple dimensión: episcopado, presbiterado y diaconado, aún con pasos significativos, sigue siendo el nudo gordiano que necesita una solución. Y esto no es nada fácil.

Por otro lado, la predicación constituye para la Iglesia el acontecimiento de la salvación, con una dimensión kerigmática, pues dimana de la soberanía de la Palabra que es proclamada, pero desde el plano de la Iglesia católica es preciso la asistencia sacramental para darle plenitud. Por eso es tan decisivo la sucesión apostólica para la existencia del ministerio ordenado o sacramento del Orden. Hasta ahora el reconocimiento mutuo de todas las Iglesias del sacramento del Bautismo, ha conseguido abrir de nuevo los caminos del respeto, comprensión y el diálogo. Se nos abre un mundo fascinante, muy atractivo, para conocer en profundidad otra dimensión cristiana de la religiosidad, de las otras Iglesias cristianas separadas en el siglo XVI que, para muchos, a día de hoy resulta totalmente desconocido. También las separadas en el siglo XI, las Iglesias ortodoxas, tenemos igualmente la experiencia de una tradición en común.

Los protestantes se separaron de la Iglesia católica en el siglo XVI. Dicha ruptura supuso la distancia doctrinal y del orden de la praxis. Muchas de ellas sólo aceptan dos sacramentos: Bautismo y Eucaristía. No hay sucesión apostólica por lo que es imposible la existencia del sacramento como lo afirma la Iglesia católica. Entre los más destacados aparecen las figuras de Martín Lutero y Juan Calvino. Se caracterizan por negar la autoridad del Santo Padre, su oposición a la cuestión de las indulgencias, el purgatorio, el sacrificio de la Eucaristía y la intercesión de los santos. Igualmente, sólo reconocen la autoridad de Cristo, como cabeza de la Iglesia; mantienen que las obras son fruto de la fe y asumen el lema de: sola fe, sola escritura, sola gracia, solo Cristo y solo gloria de Dios.

La comunión anglicana o Iglesia anglicana proviene del Reino Unido de Gran Bretaña con Enrique VIII a la cabeza. Se caracteriza porque aceptan el Misterio de Dios expresado por medio de la Santísima Trinidad; rechazan totalmente el culto a las imágenes y sus clérigos pueden contraer matrimonio. Por otra parte, los obispos anglicanos poseen la misma categoría y comparten el liderazgo de la comunidad de la Iglesia, con la participación del clero y los laicos en todas las decisiones, permaneciendo los obispos como los pastores principales. La Comunión anglicana está unida y en comunión con el arzobispo de Canterbury. También reconocen la Sagrada Escritura, pero se ofrece una amplia interpretación a la naturaleza y expresión de la inspiración, la exégesis y la interpretación de las mismas.

Las Iglesias ortodoxas se separaron de la Iglesia católica en el siglo XI. Conservan los siete sacramentos. Tienen plena coincidencia en la doctrina y mantiene todas, la sucesión apostólica. Sus obispos son sucesores de los apóstoles, por medio del sacramento del Orden. Además, la Iglesia ortodoxa constituye una comunidad de Iglesias independientes, que se denominan autocéfalas. Es decir, se hayan gobernadas por su propio obispo. Todas comparten la misma fe, los mismos principios de organización y acción eclesiástica, recogida 
por una común tradición litúrgica. Se diferencian por el uso diferente de la lengua en el culto. Esto sucede porque no asumen al sucesor de Pedro, y sin un centro de unidad, ésta se debilita. Esta es la razón de la existencia de tantas Iglesias.

Las principales Iglesias ortodoxas se pueden establecer en tres grandes grupos:

a) Las antiguas Iglesias orientales. Se separaron de la católica en el siglo V. Son la Iglesia asiria, jacobita, malankar (India), copta (Egipto), etíope y armenia. Los cuatro antiguos patriarcados, se separaron de la Iglesia católica en el siglo XI: Constantinopla, Alejandría, Antioquía y Jerusalén.

b) Las Iglesias ortodoxas que han aparecido de la subdivisión de las cuatro anteriores, según el número de fieles son: Patriarcado de Moscú; Rumanía; Grecia, Serbia; Bulgaria, etc.

c) Es preciso aclarar que con esos mismos nombres existen Iglesias católicas menos numerosas, que mantienen la unidad con Roma como los católicos malankares, coptos, armenios, caldeos, etc.

María resulta ser para todos ellos una figura excepcional, de lo que da un amplio testimonio sus grandes manifestaciones iconográficas. Estas Iglesias permiten contraer matrimonio a sus clérigos.

\section{BIBLIOGRAFÍA}

ABAD, A., "La unidad desde la perspectiva de la Iglesia Evangélica Española", en Crítica 57(2007)71-74.

AtKinson, D. J. - Field, D. H. - O'Donovan, O.- Holmes, A., Diccionario de Ética Cristiana y Teología Pastoral, Barcelona 2004, p. 784.

Andrés PuChades, A., "La Iglesia Española Reformada Episcopal", en J. García HeRnando (DIR.), Pluralismo religioso I. Confesiones cristianas, Madrid 1992, pp. 105-152.

BARón, R., "La vida litúrgica de los anglicanos", en Diálogo Ecuménico 15 (1969) 315-322.

BENEDICTO XVI, "Constitución apostólica Anglicanorum coetibus", en AAS 101 (2009) 987-990.

BARÓN, R., "La vida litúrgica de los anglicanos", en Diálogo Ecuménico 4 (1969) 315-322.

BARTH, K., La oración según los catecismos de la Reforma,Salamanca 1980;

BAUBÉROT, J., Historia del protestantismo, México 2008. 
BROWNE, E. H., Exposición histórica y doctrinal de los treinta y nueve artículos de la Iglesia Anglicana. Parte 5. Exposición de la doctrina de la Iglesia Anglicana acerca de los santos sacramentos, Londres 1875.

CABRERA, J. B., Liturgia de la Iglesia Española Reformada, Madrid 1889.

CHURCH House, Common Worship: Services and Prayers for the Church of England. Ordination Services, London 2007.

CHURCH HOUSE, Common Worship: Services and Prayers for the Church of England. Festivals, London 2008.

CHURCH House, Common Worship: Services and Prayers for the Church of England. Pastoral services, London 2015.

CHURCH HOUSE, Visual Liturgy Live, London 2006.

DE LUBAC, H., Meditación sobre la Iglesia, Bilbao 1961 y Madrid 1980.

DEARMER, P., The Ornaments of the Ministers, London 1908 y 1920.

DEVIE, M., The Church of England, London 2008.

EISENHOFER, L., Compendio de Liturgia Católica, Barcelona 1947.

ESTRUCH, J., El Protestantismo español, Barcelona 1968.

ESTRUCH, J., Los protestantes españoles, Barcelona 1967.

FRY, R., El anglicanismo en España, Madrid 1978.

García Alonso, M., La teología política de Calvino, Barcelona 2008.

García RubIO, P., La Iglesia Evangélica Española, Iglesia protestante: 125 años de vida y testimonio, Barcelona 1994.

GonzÁlez Montes, A., "El diálogo teológico católico-reformado", en P. LANGA AgUilaR, (DIR.), Al servicio de la unidad, Madrid 1993.

GonzÁlez Raposo, B., "Los matrimonios mixtos. Estado de la cuestión", en Crítica 57(2007)4751.

GounelLe, A., Los grandes principios del protestantismo, Puebla (México) 2008.

Hope, W.H. St. - AtChLey, E. G. C. F., "English Liturgical Colours", 1918, en BRADSHAW, P. F., The New SCM Dictionary of Liturgy and Worship, London 2005, pp. 120-122. 
IgLESIA ESPAÑola REFORMADA EPISCOPAL, Declaración de Doctrina. Aprobada en el Sínodo del año 1883, Madrid 1975.

IGLESIA ESPAÑOLA REFORMADA EPISCOPAL, Liturgia. Oficios Divinos y administración de los sacramentos y otros ritos, Madrid 1954, pp. 595-605.

JOHNSON, P., Historia del cristianismo, México 2006.

KASPER, W., "Acerca de la Iglesia", en Criterio 74(2001)274-280.

LEGG, J. W., Notes on the History of Liturgical Colours, London 1882.

Lehmann, P., La ética en el contexto cristiano, Montevideo 1968.

LEÓN XIII, "Bula Apostolicae curae", en ASS 329 (1896-1897) 193-203.

LEÓN XIII, "Breve dirigido al cardenal Richard, arzobispo de Paris", en ASS 329 (1896-1897) 664-665.

LEONARD, E. G., Historia General del Protestantismo, Barcelona 1967.

Liturgia Anglicana o Libro de Oración común y Administración de los Sacramentos, y otros ritos y ceremonias de la Iglesia, según el uso de la Iglesia de Inglaterra, Londres 1923.

López ARANGUREN, J. L., El protestantismo y la moral, Madrid 1954.

López ARANGuRen, J. L., Catolicismo y protestantismo como formas de existencia, Madrid 1963.

LóPEZ LozANO, C., Liturgias no romanas en lengua castellana durante los siglos XVI a XX, Salamanca 1990.

LORTZ, L., Historia de la Reforma, Madrid 1964; P. ColLINSON, La Reforma, Madrid2004.

Llamas MARTínez, E., El Anglicanismo. Origen-historia-mensaje, Salamanca 2003.

MARTínEZ, J. M., La España evangélica ayer y hoy. Esbozo de una historia para una reflexión, Barcelona 1994.

Martínez CaVero, M., La comunicación entre las Iglesias cristianas, Madrid 1970.

MATEO-SECO, L. F., Martín Lutero: Sobre la libertad esclava, Madrid 1978.

MITCHELL, L. L., Pastoral and occasional liturgies, Meryland 2007.

MitCHELL, L. L., Lent Holy Week easter and the Great Fifty Days, Meryland 2007. 
NEILL, S., El Anglicanismo, Barcelona 1966.

NEILL, S., "Necesidad del episcopado: preguntas y respuestas anglicanas", en Concilium 80 (1972) 525-536.

NEWMAN, J., Vía media de la Iglesia anglicana. Conferencias sobre la función profética de la Iglesia anglicana considerada en relación con el sistema romano y con el protestantismo popular, Salamanca 1994.

ORLANDIS, J., Historia breve del Cristianismo, Madrid $1999^{6}$.

Ruiz de Miguel, D., "Ordenación de las mujeres en la Iglesia evangélica", en VARIOS, Y....Dios creó a la mujer. XII Congreso de Teología (9-13 de septiembre 1992), Madrid 1993.

SALADRIGAS, R., Las Confesiones no católicas en España, Barcelona 1971.

TAIBO, R., Una Iglesia centenaria pero desconocida, Madrid 1980.

TAUNTON, E. L., The Law of the Church, London 1906.

Toledano, A. D., El anglicanismo, Andorra la Vieja, 1959.

TORRUBIANo RIPOLL, J., Consecuencias históricas y sociales de la Reforma, Madrid 1928.

URRUTIA, G., Iglesia y Sociedad. Una aproximación desde el pensamiento protestante, Madrid 2002.

VIDAL REGALIZA, D., Nosotros, los protestantes españoles, Madrid 1969.

VILAR, J. B., Un siglo de protestantismo en España 1893-1979, Murcia 1979.

Yetano LagunA, A., Las Iglesias cristianas en la Europa de los siglos XIX y XX, Vol. I, Madrid 1993.

\section{WEBGRAFÍA}

http://www.victorianweb.org/espanol/religion Visto 17-03-2015.

https://protocoloalavista.wordpress.com/tag/iglesia-anglicana/ Visto 17-03-2015.

http://www.churchofengland.org/about-us/history.aspx Visto 17-03-2015.

http://auladeprotocolo.blogspot.com.es/Visto 17-03-2015.

http://comunionanglicana.org/ Visto 18-03-2015 
http://www.anglicanos.org/web iglesia anglicana/g general/ga ca comunion anglican a.html Visto 18-03-2015.

http://www.anglicanos.org/web iglesia anglicana/g general/ga Im liturgia mozarabe. html Visto 18-03-2015.

http://www.churchofengland.org/about-us/history.aspx Visto 15-12-2015.

https://www.oikoumene.org/es/familias-de-iglesias/anglican-churches Visto14-11-2016.

http://www.iglesiaanglicana.org/libro/pagina17.htm Visto 14-11-2016.

https://www.oikoumene.org/es/familias-de-iglesias/anglican-churches Visto 14-11-2016.

http://www.anglicanos.org/web iglesia anglicana/g general/g ini iglesia protestante espana.html Visto 30-01-2016.

http://www.anglicanos.org/web iglesia anglicana/g general/g as iglesia espanola ref ormada.htmI Visto 30-01-2016.

http://www.anglicanos.org/web iglesia anglicana/g general/g as iglesia espanola ref ormada.htmI Visto 30-01-2016.

http://www.buzoncatolico.es/formacion/catolicismoyreligion/colores-en-la-liturgia-de-laiglesia.html Visto 18-03-2015.

http://www.iee-es.org/ Visto 30-01-2016.

http://www.iee-es.org/breve-aproximacion-historica-a-la-iglesia-evangelica-espanola/ Visto 30-01-2016.

http://www.iee-es.org/confesion-de-fe/ Visto 30-01-2016.

http://www.ehowenespanol.com/luteranismos-costumbres-tradiciones-festividadesreligiosas/Visto 30-01-2016.

http://trabajocristianoortodoxoyprotestante.com.es/las-festividades.html Visto30-01-2016.

http://justus.anglican.org/resources/bcp/Spain/Special Days.htm\#Circumcision Visto 30-01-2016.

http://justus.anglican.org/resources/bcp/Spain/Special Days.htm\#Epiphany Visto 30-01-2016. 
http://iustus.anglican.org/resources/bcp/Spain/Special Days2.htm\#easter Visto 30-01-2016.

http://justus.anglican.org/resources/bcp/Spain/Special Days2.htm\#pentecost Visto 30-01-2016.

http://iustus.anglican.org/resources/bcp/Spain/Special Days2.htm\#trinity Visto 30-01-2016.

http://iustus.anglican.org/resources/bcp/Spain/Special Days2.htm\#ascension Visto 30-01-2016.

http://www.teologiamoral.com/ecumenismo/ Visto 30-01-2016.

http://www.ehowenespanol.com/luteranismos-costumbres-tradiciones-festividadesreligiosas/Visto 30-01-2016.

http://www.stgeorgesmadrid.org/

Visto 16-12-2015.

http://www.anglicanos.org/

Visto 16-12-2015.

http://www.iee-es.org

Visto 16-12-2015.

http://www.friedenskirche.es/

Visto 16-12-2015.

http://www.presbiterianoreformado.org/estandares/

Visto 30-01-2016.

http://justus.anglican.org/resources/bcp/Spain/burial.htm

Visto 30-01-2016.

http://es.scribd.com/doc/115397065/Rito-funebre-segun-Iglesia-Evangelica Visto 30-01-2016.

http://www.ehowenespanol.com/luteranismos-costumbres-tradiciones-festividadesreligiosas/Visto 30-01-2016.

http://protocoloeclsiasticoymilitar.blogspot.com.es/ Visto 30-01-2016. 
http://www.eventoygestion.net/2012/08/tratamientos-religiosos.html Visto 30-01-2016.

(c) 1 This work is licensed under a (1) 